\author{
Anna Jungiewicz \\ Uniwersytet Jagielloński, Kraków \\ ankajun@gmail.com
}

\title{
Marcina Białobrzeskiego Kazanie o przyjmowaniu ciała i krwie Pana Jezu Krysta pod jedna osobq
}

\begin{abstract}
Marcin Białobrzeski’s Kazanie o przyjmowaniu ciała i krwie Pana Jezu Krysta pod jedna osoba (A Sermon on the Reception of the Body and Blood of Lord Jesus Christ under One Kind)
\end{abstract}

The objective of this edition of Marcin Białobrzeski's Kazanie o przyjmowaniu ciała $i$ krwie Pana Jezu Krysta pod jedna osoba is to remind an important voice in the discussion between Catholics and Protestants about the manner of receiving the sacrament of the Eucharist under one or two kinds. Beginning with Jan Hus, one of the postulates raised by the supporters of the reform of the Catholic Church was to introduce the practice of administering Holy Communion to the laity under two kinds, to which the Catholic Church's legislation opposed. In Protestant communities, the Eucharist was administered under both kinds and lay Catholics also demanded the introduction of this practice. In 1578, in response to ever more frequent postulates, bishop Marcin Białobrzeski gave the Good Thursday sermon in Kamieniec Podolski, in which he explained to the audience the reasons why Catholics were administered Holy Communion under one kind only. The sermon was written down and published a year later in Cracow in the press house of Andrzej Piotrkowczyk, and next included in a collection of his sermons entitled Postylla ortodoxa (1581) as a sermon for Good Thursday. 
The bishop mainly called for retaining love and unity recommended by Jesus during the last supper. The main message of the sermon was to prove the complete sufficiency of receiving the Eucharist under the form of bread only. He also strove to demonstrate that the Eucharistic kinds are disproportionately insignificant as compared to the question of faith in Christ's sacramental presence in the Holy Communion. Białobrzeski drew his arguments from the Holy Scripture, the writings of the Church Fathers, the council and synodal legislation, as well as from the studies of history and nature. Apart from the rational line of thought, he also tried to convince his listeners to this practice by engaging in an apparent dialogue with them.

Key words: Marcin Białobrzeski, Catholic Reformation, sermons, the Holy Eucharist

Z tem większą pewnością spodziewać by się należało obfitego materiału $\mathrm{z}$ lat 1559-1586, kiedy rządy klasztoru dzierży Marcin Białobrzeski vir litteratus w całym tego słowa znaczeniu, najznakomitszy obok Wujka i Skargi homileta polski, który buduje dla siebie wspaniałą rezydencję renesansową, i na pomieszczenie archiwaliów stwarza nowy przybytek, którego odrzwia kamienne z napisem «BURSARIA MONASTERII 1569», dotąd się zachowały ${ }^{1}$.

W tych słowach wyraził zdziwienie o. Gerard Kowalski, gdy przystępował do opracowywania katalogu archiwum opactwa cystersów w Mogile. Postać Białobrzeskiego zapisała się złotymi zgłoskami w historii zakonu cystersów na ziemiach polskich, jednak zapiski w sensie ścisłym zaginęły. Zdziwienie ojca Gerarda zmalało, gdy poznał dalszą historię opactwa. Rządy po Marcinie Białobrzeskim obejmują opaci komendatoryjni, wybierani na to stanowisko przez władzę świecką, rekrutujący się najczęściej z potężnych rodzin magnackich. Przypuszczać można, że zaginione dokumenty, których brakuje w archiwum mogilskim, opuściły jego mury, by zasilić księgozbiory rodów opatów komendatoryjnych. Niektóre rękopisy zniknęły z archiwum mogil-

1 Katalog Archiwum opactwa cystersów w Mogile, oprac. K. Kaczmarczyk, G. Kowalski, Kraków 1919, s. XXII. 
skiego inną drogą - niejaki Erwin Redl jeździł po wielu klasztorach, przedstawiał się jako pracownik naukowy, wypożyczał co cenniejsze rękopisy, które następnie sprzedawał bogatym bibliofilom. Archiwum mogilskie było również odwiedzane przez wysłanników Załuskiego, Czackiego i Ossolińskiego, co także spowodowało zubożenie zbioru o kolejne egzemplarze. I tak niektóre rękopisy, dyplomy oraz kronika rękopiśmienna znajdują się obecnie w Bibliotece Książąt Czartoryskich w Krakowie. Mogiła ze swym archiwum nie oparła się również inwazji szwedzkiej; wiadomo, że Szwedzi splądrowali bibliotekę, nie wiadomo natomiast, co padło ich łupem. Informacje biograficzne o wielkim opacie przynosi dopiero kronika Sebastiana Kiełczewskiego „Historia monasterii Clarae Tumbae cum serie abbatum et fratrum", spisana w drugiej połowie XVII wieku. Rozprawa ta częściowo opiera się na kronice zmarłego w 1506 roku Mikołaja z Krakowa, który doprowadził kronikę zakonu do czasu sobie współczesnego. Historia Kiełczewskiego do chwili obecnej pozostaje w rękopisie, prace nad jej wydaniem i tłumaczeniem prowadzi Jacek Partyka, choć sam autor wyraził życzenie, aby jego dzieło nie zostało przetłumaczone na język polski i pozostało do odbioru tylko w kręgu duchownych ${ }^{2}$.

$\mathrm{Z}$ zachowanych dokumentów wiadomo, że Białobrzeski został mianowany opatem Mogiły na miejsce swojego wuja i 18 sierpnia 1560 roku oficjalnie objął ten urząd. To właśnie wuj, Andrzej Spot, zaprosił Marcina do Mogiły, gdy ten przebywał w opactwie w Sulejowie, gdzie złożył śluby zakonne. Wuj zatroszczył się również o wykształcenie siostrzeńca w Akademii Krakowskiej, w której ukończył on prawo i teologię, a oprócz łaciny poznał także grekę. Encyklopedia katolick $a^{3}$ wspomina też o edukacji za granicą, nie wiadomo jednak, gdzie i w jaki sposób ona przebiegała, informacji tej nie potwierdzają inne źródła. Poza godnością opata piastował również urząd sufra-

2 Biblioteka Książąt Czartoryskich, rkps 3652.

3 M. Brzozowski, Marcin Białobrzeski, w: Encyklopedia katolicka, red. F. Gryglewicz, R. Łukaszyk, Z. Sułowski, t. 2: Bar-Centuriones, Lublin 1976, s. 365. 
gana przy biskupie krakowskim, kanonika w katedrze krakowskiej, a także biskupa kamienieckiego i laodycejskiego. Według Encyklopedii katolickiej ${ }^{4}$ osobiście wizytował swoją diecezję, regularnie głosił kazania. Był także zaangażowany w działalność społeczno-polityczną - wygłosił kazanie na pogrzebie Zygmunta Augusta, był stronnikiem Habsburgów po ucieczce Walezego z Polski, delegatem na zjeździe stężyckim (1575) i jędrzejowskim (1576), sprawował również misje dyplomatyczne w Wiedniu i był przedstawicielem króla Batorego na pogrzebie jego brata Krzysztofa de Somlyo. Sprawując obowiązki kościelne i polityczne, równocześnie wciąż pozostawał opatem Mogiły i - wreszcie - czytał i pisał. Pierwszym jego dziełem jest Orthodoxa Confessio de uno Deo, quem Christiani Catholici credunt, adorant et invocant [...], spisane po łacinie wyznanie wiary skierowane przeciw arianom. W języku polskim napisał Katechizm albo Wizerunk prawéj wiary chrześcijańskiej, wedle nauki Pana Jezusa Chrystusa, Apostołów Jego, i Kościoła Jego Świętego, przeciwko wszystkim obłędliwościam tych czasów, barzo pożyteczny. Katechizm ma formę dialogu między mistrzem a dociekliwym uczniem, domagającym się wyjaśniania spornych kwestii. Dialog ten omawia zdanie po zdaniu Symbol nicejsko-konastantynopolitański i Modlitwę Pańską, główne prawdy wiary oraz wszystkie „świątości nowego Zakonu", czyli sakramenty. Adresatami tych dzieł byli przede wszystkim ci wierni, którzy z braku racjonalnych argumentów zaczynali mieć wątpliwości co do słuszności swojego wyznania. Białobrzeski napisał jeszcze rozprawę po łacinie Sacrosancti sacrificii missae assertio ex sacris litteris sanctorumque et vetustissimorum patrum scriptis breviter collecta, ale dziełem jego życia pozostaje Postylla ortodoxa, w skład której weszło wielkoczwartkowe kazanie o przyjmowaniu ciała Chrystusa pod jedną postacią.

Opat jawi się więc jako niezwykle pracowity człowiek, który potrafił połączyć obowiązki na różnych polach i równocześnie doprowadził powierzony sobie dwór mogilski do rozkwitu. W Postylli jed-

4 Ibidem. 
nak wielokrotnie poddawał krytyce dwory i zasady na nich panujące, epitetu „dworny” używał zawsze w ujemnym znaczeniu. Białobrzeski sam pochodził z rodziny szlacheckiej - i ojciec Janusz (h. Abdank), i matka Anna z Janikowskich (h. Jastrzębiec) byli szlacheckiego rodu, podobnie wuj, wspomniany Andrzej Spot. Co więcej, Białobrzeski w roli dyplomaty odwiedzał liczne dwory europejskie, wywiązując się skutecznie $\mathrm{z}$ powierzonych misji, należał również do elity doradczej królów Zygmunta Augusta i Stefana Batorego, co wskazuje zdecydowanie na jego obycie i zorientowanie w środowisku dworskim. W kazaniach jednak obnaża i krytykuje mechanizmy rządzące tym środowiskiem. W archiwum mogilskim znajdują się dokumenty świadczące o gospodarności opata, o trosce o powierzone dobra, a także o poddanych - jeden z dyplomów poświadcza spór między klasztorem a Erazmem Strusiem, dzierżawcą Prandocina, który „wbrew kontraktowi uciska poddanych i zalega z czynszem od dwóch lat" ${ }^{5}$. Przedsiębiorczości opata dowodzą również rozbudowa klasztoru, przetopienie złotych kielichów liturgicznych, posążka Matki Boskiej i hermy na zastawę stołową, przenoszenie dóbr biskupstwa kamienieckiego w głąb kraju przez wymianę, budowa grobowca dla siebie za życia oraz nowego pomieszczenia dla archiwum, a także nieustanne poszerzanie księgozbioru. To właśnie księgozbiór był przedmiotem szczególnej troski opata. Systematycznie nabywał on nowe tytuły, księgi oprawiał w skórę i opatrywał swoim superekslibrisem ${ }^{6}$; to z czasów jego pieczy nad klasztorem pochodził pierwszy inwentarz biblioteki klasztornej, który niestety nie dochował się do dziś. Białobrzeski przywiózł z węgierskiego Osjaku do Polski żywot Bolesława Szczodrego, utrzymywał aktywny kontakt ze współczesnymi literatami (Andrzej Trzecieski, Jan Grotowski) i - przede wszyst-

5 Katalog inkunabułów Biblioteki Opactwa Mogilskiego oraz katalog inkunabułów klasztoru cystersów w Szczyrzycu, opisał G. Kowalski, Kraków 1915, dokument nr 256, s. 87.

${ }^{6}$ Był to wytłoczony na oprawie herb Abdank i napis Frustra vivit qui nemini prodest 1577 oraz napis M[artinus] B[ialobrzescus] E[piscopus] C[amnecensis] A[bbas] C[laratumbiensis]. 
kim - czytał. O zamiłowaniu Białobrzeskiego do lektury napisał Jan Grotowski w następujący sposób: „We dnie i także w nocy leży nad księgami [...] Jest to jego muzyka ksiąg pilne czytanie" są obecne w postylli, która przybliżyła polskojęzycznemu czytelnikowi dorobek myśli chrześcijańskiej od starożytności po współczesność opata. Obraz takiego bibliofila jawi się czytelnikowi, który po upływie przeszło czterech wieków sięga po dzieła Białobrzeskiego.

Postylla ortodoxa, to jest Wykład świętych Ewanjelij niedzielnych $i$ świąt uroczystych przez cały rok, $z$ Pisma Świętego $i z$ Doktorów Kościoła Powszechnego, z wielka praca zebrany i ku nauce wiernych chrześcijańskich ludzi z pilnościa napisany jest dziełem kompletnym, odgrywającym znaczącą rolę w piśmiennictwie schyłku XVI wieku, o czym może świadczyć fakt, że synod diecezjalny kujawski z 1586 roku zalecił ją do czytania plebanom. Warto więc podjąć próbę umiejscowienia zbioru Marcina Białobrzeskiego na mapie ówczesnej postyllografii. W postyllach znalazło odbicie zarówno odejście od scholastycznych rozważań na korzyść uważnej interpretacji tekstu Pisma Świętego na wzór pierwszych kazań i homilii chrześcijańskich, jak i dążenie do odnowienia i zreformowania Kościoła. Jako gatunek postylla stała się funkcjonalnym nośnikiem idei i postulatów dla ludzi domagających się reformy czy otwarcie występujących ze struktur Kościoła, a potem także dla ich oponentów. Po gatunek postylli najpierw sięgnął Marcin Luter w wygłaszanych przez siebie w latach 1532-1534 kazaniach, które zostały wydane drukiem w 1544 roku, a do Polski trafiły w roku 1574 za sprawą tłumaczenia Hieronima Maleckiego. Pierwszą napisaną w języku polskim była Postylla polska domowa Grzegorza Orszaka (1556), rok po niej Świętych słów a spraw Pańskich [...] kronika albo postylla, polskim językiem a prostym wykładem też dla prostaków krótce uczyniona Mikołaja Reja, po niej zaś wydane zostało wspomniane wyżej tłumaczenie postylli Lutra. Katolicką odpowiedzią na postyllę Reja była Postylla catholica,

7 J. Grotowski, Sokrates albo o szlachectwie rozmowa [...], [Kraków: Łazarz Andrysowicz, b.r.w.], k. $\mathrm{B}_{4} \mathrm{v}$. 
to jest Kazania na każda niedzielę i na każde święto przez caly rok Jakuba Wujka, na którą z kolei odpowiedział Grzegorz z Żarnowca w dziele Postylla albo wykład Ewanielij Niedzielnych i Świąt uroczystych. W podobnym czasie ukazała się Postylla ortodoxa Marcina Białobrzeskiego, często określana jako wymierzona przeciwko arianom, w gruncie rzeczy wymierzona przeciw wszystkim herezjom, podająca pozytywny wykład wiary i niewchodząca w bezpośredni dialog z żadną z postylli innowierczych.

Pierwszeństwo chronologiczne $\mathrm{w}$ polemicznej postyllografii należy do luteranów. W środowisku wiernym papiestwu również dostrzeżono i podkreślono niebagatelną rolę, jaką odgrywały kazania w przekazywaniu wiary i nauki Kościoła, szczególny zaś nacisk położono na kaznodziejstwo biskupów. 11 listopada 1563 roku na 24. sesji Soboru Trydenckiego zatwierdzono przepisy dotyczące kaznodziejstwa i zebrano je w kanonie 4: „Kto ma obowiązek głoszenia kazań; głoszenie słowa Bożego w kościołach parafialnych; by nikt nie głosił kazań bez zgody biskupa" (Praedicationis munus a quibus et quando obeundum; ecclesia parochialis ad audiendum verbum Dei adeunda. Nullus contradicente episcopo praedicet) ${ }^{8}$. Według niego obowiązek ten spoczywał na biskupach lub - w razie przeszkód na wyznaczonych kapłanach, także na duchownych pracujących w duszpasterstwach parafialnych. Kazania miały być głoszone w niedziele i uroczyste święta9. Autorzy Encyklopedii katolickiej ${ }^{10}$ ukazują postyllę Białobrzeskiego jako wymierzoną $\mathrm{w}$ arian. Istotnie, Białobrzeski wielokrotnie zwraca się przeciw nim $\mathrm{w}$ tonie polemicznym, trzeba jednak zauważyć, że arianie byli przez oponentów - i to zarówno katolików, jak i luteranów i kalwinistów - traktowani jako ucieleśnienie wszelkich herezji i błędów, stąd polemika z nimi była

8 Dokumenty soborów powszechnych. Tekst łaciński i polski, t. 4: (1511-1870) Lateran V, Trydent, Watykan I, układ i oprac. A. Baron, H. Pietras, [tłum. A. Baron et al.], Kraków 2004, s. 743.

9 K. Panuś, Zarys historii kaznodziejstwa $w$ Kościele katolickim, cz. 2: Kaznodziejstwo w Polsce, t. 1: Od średniowiecza do baroku, Kraków 2001, s. 196.

10 M. Brzozowski, Marcin Białobrzeski... 
częsta i intensywna. U Białobrzeskiego jednak, jak już wspomniano, dotyczy ona wszystkich herezji, które przeciwstawiają się katolickiej wykładni. Interpretacja następujących po sobie zdań perykop ewangelicznych sprowadzała się do przedstawienia kolejnych dogmatów, prawd wiary, czynności liturgicznych czy elementów sprawowania kultu. Jeśli podczas takiej interpretacji Białobrzeski napotykał odmienności między wykładnią Kościoła rzymskokatolickiego a innego obrządku lub sekty, omawiał je dogłębnie. W ten sposób stworzył wyczerpujący wykład spornych miejsc Pisma Świętego i przegląd herezji, które na ich podstawie powstały. W kazaniu wygłoszonym na pogrzebie króla Zygmunta Augusta biskup i opat wyraził następującą pochwałę króla: „Pan nasz nieboszczyk w to ugodzić umiał, że nigdy do szkodliwego rozerwania między niezgodnymi w wierze nie przyszło, acz się do złego częstokroć barzo zanosiło"11. Jest to swoista pochwała tolerancji religijnej i zachowania pokoju między różnowiercami. Mirosław Korolko odczytuje to jako obraz światopoglądu biskupa kamienieckiego, który mimo wyraźnej niechęci do heretyków i mimo stanowiska episkopatu, który dążył do wzmocnienia katolicyzmu na ziemiach Rzeczypospolitej, a które Białobrzeski oficjalnie podzielał, nie uznawał rozwiązań siłowych i uważał, że „naukę Chrystusową należy upowszechniać nie za pomocą oręża, lecz przez nacechowaną miłością perswazję"12. Jest to również przyczynek do opisu sytuacji, jaka panowała na ziemiach Rzeczypospolitej po upowszechnieniu się na nich nauk protestanckich. Na pierwszy plan w postylli wysuwa się nie tyle rys polemiczny, ile aspekt pozytywny, racjonalistyczny.

Jest ona dla wiernego czytelnika polskojęzycznego przybliżeniem dorobku zarówno ojców Kościoła, jak i ówczesnych myślicieli i historyków. Inspiracją i źródłem materiału inwencyjnego było z pewnością dzieło karmelity Thomasa Beaulxamisa Homiliae in omnia,

11 M. Białobrzeski, Kazanie na pogrzebie Zygmunta Augusta, w: Kazania funeralne, oprac. K. Panuś, M. Skwara, Kraków 2014, s. 88.

12 M. Korolko, Klejnot swobodnego sumienia. Polemika wokót konfederacji warszawskiej w latach 1573-1658, Warszawa 1974, s. 63. 
quae per Quadragesimam leguntur Evangelia, wydane w 1576 roku, a więc na krótko przed powstaniem postylli. Innym źródłem były Cornelii Jansenii [...] Commentariorum in suam Concordiam ac totam Historiam Evangelicam, w których Korneliusz Jansen Starszy podał egzegetyczny i patrystyczny komentarz do czterech Ewangelii. W wielu przypadkach Białobrzeski podaje analogiczne odniesienia do ojców Kościoła - czy jest to dzieło przypadku, czy też świadome naśladownictwo, niełatwo o tym wydać pewny sąd; odwołanie do dzieła tego teologa w marginaliach może wskazywać na tę drugą możliwość. Marcin Białobrzeski nie sięga po inwektywy, wielokrotnie zdradza oburzenie i irytację („Kiedy by to rzékł i napisał powszechnégo rzymskiégo Kościoła Doktór który, jakie by nań krakanié, jakie wołanié, jakie by łajanie było! Lecz iż Luter, który sie zowie piątym ewanjelistą, wtórym Elijaszem, prorokiem, który skały kruszy, to mówił - a to od niego wszytko wdzięcznie przyjmują"13), jednak konsekwentnie obstaje przy rzeczowej polemice.

Odżegnywanie się od retoryki było w szesnastowiecznej literaturze europejskiej toposem, mającym źródła w Erazmowym Ciceronianusie, przy czym sama realizacja utworu literackiego często pozostawała w sprzeczności z deklarowaną rezygnacją. Marcin Białobrzeski również zapowiada podawanie w kazaniu „prosto i łacwie” „prawdy szczérej”, „bez sofistyjéj”; epitetów „dworny” i „subtylny” używa jako wartościujących ujemnie daną rzecz, szczególnie w odniesieniu do bezużytecznych badań i dywagacji. Deklarowana prostota i dystans wobec dworskości nie pozostają jedynie postulatami bez pokrycia. Sprzyja temu sama właściwość gatunku postylli, o której była mowa powyżej. Kaznodzieja rezygnuje także $\mathrm{z}$ chwytów przyciągających uwagę we wstępach do kazań, $\mathrm{z}$ afektowanej skromności, nie używa amplifikacji, ogranicza części narracyjne, trzyma się zasadniczo porządku Ewangelii, pozwalając sobie jednak na dygresje, w pole-

13 M. Białobrzeski, Postylla ortodoxa, to jest Wykład świętych Ewanjelij niedzielnych i świąt uroczystych przez cały rok [...]. Część pierwsza, od Adwentu do Wielkiejnocy, Kraków 1581, s. 438. 
micznym aspekcie kazań pozostaje stonowany i rzetelny. Ten właśnie aspekt kazań sprawia, że ich konstrukcja retoryczna była w całości nakierowana na odbiorcę -

hipotetycznego, wyposażonego w sprecyzowany zespół przekonań, który stawiał opór i w ten sposób włączał się jako pozornie zewnętrzny i milczący wprawdzie, ale ważny partner dialogu, ponieważ wszelkie wypowiedzi w obrębie tekstu obliczone były na jego świadomość, na rozeznawany przez niego system wartości i stosunek do świata ${ }^{14}$.

W tym miejscu zauważyć trzeba, że kazania Białobrzeskiego realizują model określony przez Steca mianem „podwójnej dialogowości”. Kaznodzieja polemista prowadzi bowiem dialog nie tylko z tymi, do których mówi, ale też z tymi, o których mówi. Najwyraźniej struktura ta ujawnia się w stawianych pytaniach: „Pytasz, czemu?” - skierowanych do odbiorców bezpośrednich oraz „Pytałby, czemu?” - skierowanych do oponentów. Trudno sądzić, aby wśród słuchaczy kazań znaleźli się różnowiercy, polemika z nimi rozgrywana była pośrednio - bezpośredni, katoliccy odbiorcy mieli wysłuchać odparcia innowierczych zarzutów, by potem, już poza kościołem, w miejscu debaty móc podjąć rzeczową dyskusję.

Zasadniczy tekst kazań jest w całości napisany w języku polskim (również wszelkie cytaty), wolny od niezrozumiałych wskazówek bibliograficznych i źródłowych. Te informacje znajdują się w marginaliach, pisanych w trzeciej osobie, zdających się raczej dziełem redaktora, w samym tekście pojawia się jedynie zdawkowe „pogański poeta” lub ,jeden”, „pewien”. W ten sposób słuchacz nie otrzymywał niezrozumiałych informacji, a niewykształcony ksiądz zostawał zaopatrzony w warsztat pozwalający mu się dokształcić. Białobrzeski często parafrazuje wypowiedzi Jezusa lub innych bohaterów Ewangelii, rozwija je, by pokazać, co mieli na myśli. Bardzo często po przytoczonym zdaniu Jezusa umieszcza zwrot „Jakoby rzékł”, będący

14 W. Stec, Literacki ksztalt polskich polemik antyjezuickich z lat 1578-1625, Białystok 1988, s. 30. 
kalką łacińskiego zwrotu quasi dicat. Po takim zwrocie następuje parafraza, dopowiedzenie tego, co mogłoby być w wypowiedzi Chrystusa niezrozumiałe, wyjaśnienie pewnych realiów, odwołanie do innych miejsc w Piśmie Świętym, w których opisano podobną sytuację. Zdarzenia ewangeliczne interpretuje nie tylko na poziomie literalnym, ale też alegorycznym, moralnym i anagogicznym. Przykładem może być Kazanie na Ewanjelija w II niedzielę Postu, w którym wiara Syrofenicjanki zostaje zinterpretowana jako wzór do naśladowania dla wierzącego, ale też jako wizerunek Kościoła zwracającego się do Pana w potrzebach.

Elokucja kazań sprowadza się w dużej mierze do tego, że prawdziwość wiary katolickiej jest nieustannie zderzana w szyku antytetycznym z prawdami uznawanymi przez innowierców, przez co kazania zyskują wymiar komparatystyczny. Białobrzeski porównuje głównie prawdy wiary, ale także liturgię, „cerymonije”, zwyczaje, a nawet architekturę. Choć stosuje często zdania porwane, to jednak rzadko używa finalnego szyku orzeczenia i antycypacyjnego szyku zdań. Przeważają zdania proste lub złożone w sposób nieskomplikowany, szczególnie częste są proste antytezy. Trudno osądzić, czy kazania $\mathrm{z}$ tego zbioru zostały kiedykolwiek wygłoszone, a jeśli tak, to czy wszystkie, czy tylko część. Kazanie o przyjmowaniu ciała $i$ krwie z pewnością zostało zrealizowane na kazalnicy. Pojawiają się w nim sygnały bezpośredniego kontaktu z publicznością, pozostałe natomiast zawierają uwagi w stylu „o tymem pisał na inszym miejscu”, wskazujące na proces pisania. Można jednak podjąć próbę doszukania się w kazaniach scenariusza zachowań retorycznych. Uwaga odbiorcy koncentruje się na podtrzymywanej strukturze dialogowej, na pozornym dopuszczeniu do głosu i do zadawania pytań. Struktura taka sprawdza się zarówno w literaturze mówionej, jak i pisanej. Ponadto Białobrzeski często wtrąca wyjaśnienia, tłumaczenia niezrozumiałych zwrotów; jest to przerwanie głównego wywodu, zwrot do publiczności z wyjaśnieniem, coś, co nie tylko ma pomóc w zrozumieniu, ale też wzbudzić sympatię i przychylność. Autor rzadko odwołuje się do uczuć, tak jak rzadko stosuje wykrzyknienia. Przeważa 
zdecydowanie wewnętrzna topika inwencyjna, żywiołem kaznodziei jest myśl i intelektualny dyskurs.

W dyskusjach i polemikach toczonych między katolikami a różnowiercami na przełomie XVI i XVII wieku poczesne miejsce - obok tematu miejsca Chrystusa w Trójcy Świętej i jego natury boskiej i człowieczej - zajmował temat Eucharystii. Najwięcej wysiłku i uwagi wkładano w dyskusje na temat sposobu obecności ciała i krwi Pańskiej w tym sakramencie, charakteru ofiarniczego i urzeczywistniającego sprawowanej liturgii, wreszcie kształtu poszczególnych obrzędów, między innnymi właśnie udzielania Komunii Świętej bądź to pod jedną tylko, bądź pod dwiema postaciami. Pragnienie przyjmowania Eucharystii pod postaciami chleba i wina przez wiernych zostało dobitnie sformułowane przez Jana Wiklefa, Jana Husa, a powtórzone przez Marcina Lutra i Jana Kalwina. Z opisów ewangelicznych ${ }^{15}$ jasno wynika, że Jezus ustanowił sakrament Eucharystii pod dwiema postaciami, chleba i wina, a znak wina w myśli teologicznej był rozpatrywany w kontekście zarówno odkupieńczej męki Chrystusa, a co za tym idzie ofiarniczego wymiaru Eucharystii ${ }^{16}$, jak i eschatologicznej uczty zbawionych. Przyjmowanie więc Komunii pod obiema postaciami przez całą wspólnotę pozwalało na pełne ukazanie bogactwa tych znaków i odniesienie się zarówno do symboliki chleba, jak i wina. Analiza listów i katechez ojców Kościoła oraz najstarszych opisów Eucharystii wykazuje, że zwyczaj udzielania Komunii Świętej pod tymi dwiema postaciami był powszechny w starożytności i we wczesnym średniowieczu ${ }^{17}$. Później stopniowo zanikał, w drugiej połowie XIII wieku św. Tomasz z Akwinu opisuje udzielanie ludowi Komunii pod jedną postacią jako ugruntowaną praktykę. Odejście od pierwotnego sposobu było podyktowane

15 Mt 26; Mk 14; Łk 22.

16 J. Możejko, Praktyka Komunii świętej pod obiema postaciami, „Liturgia Sacra” 20 (2014), nr 2(44), s. 378.

17 M. Zachara, Komunia święta pod obiema postaciami, „Pastores” 65 (2014), nr 4, s. 124. 
racjami praktycznymi, $\mathrm{w}$ rozumieniu teologicznym nie pojawiła się żadna przesłanka, która nakazałaby wstrzymywanie udzielania wiernym sakramentalnego znaku wina. Jako powody wymieniało się i wymienia nadal trudność w oszacowaniu właściwej ilości wina potrzebnej do konsekracji, przesadną obawę co do niewłaściwego obejścia się z konsekrowanym winem, szczególnie podczas zanoszenia go do chorych lub więźniów, niechęć do picia $\mathrm{z}$ jednego naczynia przez wiele osób z powodów higienicznych, nierówną dostępność wina $\mathrm{w}$ niektórych miejscach czy udzielanie dwóch postaci sakramentalnych niepełnoletnim.

Głównymi dwoma celami kazania na dzień wieczerzy Pańskiej Marcina Białobrzeskiego są ukazanie niewspółmierności niewielkiej wagi problemu postaci eucharystycznych wobec ogromu miejsca, jakie poświęca się mu w polemikach, przy zaniedbaniu innych, o wiele ważniejszych kwestii związanych z Eucharystią, a także przeprowadzenie dowodu o zupełnej wystarczalności do zbawienia przyjmowania Komunii pod postacią chleba. Wokół tych tez Białobrzeski gromadzi argumenty zarówno skrupturystyczne, z pism ojców Kościoła i z tekstów Soboru Trydenckiego, jak i argumenty naturalne.

Temat kazania zaczerpnął z Ewangelii Janowej: „umiłowawszy swoich na świecie, do końca ich umiłował"18 (J 13,1), wskazując na ofiarę eucharystyczną, ustanowioną w Wieczerniku, a przypieczętowaną na Golgocie, jako największy znak miłości Chrystusowej. W części egzordialnej kazania wymienia dwojakie dobrodziejstwo, które uczynił Chrystus z miłości do człowieka, a mianowicie ustanowienie ofiary eucharystycznej i kapłaństwa. Sakrament kapłaństwa został przez Białobrzeskiego rozwinięty uprzednio w katechizmie, kazanie zostało całkowicie poświęcone Eucharystii. W części narracyjnej kaznodzieja opisuje szerzej powody, dla których Chrystus pozostawił swoje ciało i krew pod postaciami chleba i wina. Było ich kilka, jednak najważniejszy to ustanowienie jedności i miłości -

18 Cytaty biblijne za: Pismo Święte Starego i Nowego Testamentu [Biblia Tysiąclecia], wyd. 4, Poznań 1984. 
na wzór jedności chleba utworzonego z wielu ziaren i wina wytoczonego z wielu gron. Jedność, o którą gorąco prosił Chrystus $\mathrm{w}$ modlitwie podczas ostatniej wieczerzy, została zniweczona przez roztrząsanie podrzędnych kwestii związanych z poszczególnymi obrzędami. Białobrzeski wymienia trzy najpoważniejsze rozłamy na tle różnego podejścia do Eucharystii: schizmę między Kościołami wschodnim a zachodnim, której jednym z powodów była niezgoda co do używania kwaszonego bądź przaśnego chleba, odłączenie się Kościołów reformowanych, spowodowane między innymi różnicą w pojmowaniu obecności Chrystusa w sakramentalnych znakach, oraz zupełne rozłączenie postaci chleba i wina, udzielanych w Komunii osobno. W tej pierwszej części najpierw został zawarty wykład pozytywny o jedności chrześcijańskiej, wypływającej z miłości traktowanej jako pierwsze spośród przykazań, z którym to wykładem zostały skonfrontowane przeciwne mu nauki.

W kolejnej, najobszerniejszej części kazania, argumentatio, Białobrzeski najpierw przytacza trzy kontrargumenty różnowierców, które następnie zbija, budując na tym wykład pozytywny o sakramentach w ogólności, a o sakramencie Eucharystii w szczególności. Są to po kolei: przekonanie o konieczności przyjmowania ciała i krwi Chrystusa w celu otrzymania życia wiecznego, wynikające $\mathrm{z}$ jego słów: „Jeżeli nie będziecie spożywali Ciała Syna Człowieczego i nie będziecie pili Krwi Jego, nie będziecie mieli życia w sobie” (J 6,53); przykład płynący z ostatniej wieczerzy, kiedy to sam Chrystus rozdawał i chleb, i wino; użyte przez Jezusa podczas tejże wieczerzy słowo „wszyscy”, które zobowiązuje Kościół do udzielania obu postaci całej społeczności wiernych. Opat określa te argumenty jako zbyt mało znaczące, by zagroziły jedności chrześcijan, a wykorzystywanie ich do szerzenia rozłamów uważa za nadużycie i zapowiada wyjaśnienie każdej z tych kwestii. W tym miejscu następuje pozytywny wykład, dlaczego Komunia Święta jest udzielana świeckim pod jedną postacią. Najpierw zostają przytoczone argumenty historyczne: Jezus w Emaus i św. Ignacy Antiocheński udzielali Komunii tylko pod postacią chleba, taki sposób spowodowany był przez wzgląd na osoby składające ślub nazireatu, podejmujące tym samym abstynencję, 
w Polsce tradycja tylko chleba panowała od samego przyjęcia chrztu. Biskup przypomina, że już sobory w Konstancji i Bazylei wstrzymały postać wina, by uśmierzyć liczne herezje. Miało to na celu zapobieżenie nestoriańskiemu zwyczajowi konsekracji pojedynczych postaci eucharystycznych, a także niewierze w prawdziwą obecność Jezusa w sakramentalnych znakach, zapoczątkowanej przez Berenagariusza, a kontynuowanej przez Ulricha Zwingliego i Jana Kalwina. Postanowienia soborowe miały ukrócić też teorie, według których wino jest cenniejszą postacią eucharystyczną, oraz nieuszanowanie często nieintencjonalne - tej postaci podczas udzielania Komunii chorym lub zgromadzonym.

W końcu Białobrzeski zwraca uwagę na to, że niektórzy ludzie $z$ różnych przyczyn nie mogą spożywać wina, a także są takie krainy, gdzie wino nie występuje i jest bardzo drogie, wobec czego udzielanie Komunii pod postacią wina jest niezasadne. Wykazawszy, dlaczego wino jako znak eucharystyczny nie jest powszechnie udzielane, wskazuje na kompletną wystarczalność samego znaku chleba, opierając się na czterech fragmentach z Ewangelii św. Jana, w których Jezus mówi o chlebie życia (J 6,35), zapowiadając ustanowienie Eucharystii. Białobrzeski tłumaczy, że kapłani sprawują i przyjmują Eucharystię pod dwiema postaciami, by ukazać pełnię sakramentalnego znaku, jednak pochodzące z konsekracji zdanie „bierzcie i pijcie z niego wszyscy” już w samym momencie ustanowienia Eucharystii nie obejmowało na przykład 72 uczniów czy też niewiast. Na koniec, w części peroracyjnej, kaznodzieja inicjuje modlitwę o Ducha jedności i miłości oraz głosi chwałę Boga. Jak wynika $\mathrm{z}$ wiersza dołączonego do osobnej edycji tego kazania, spotkało się ono z wdzięcznym przyjęciem przez mieszkańców Podola.

\section{Podstawa edycji}

Marcin Białobrzeski, Postylla ortodoxa, to jest Wykład świętych Ewanjelij niedzielnych $i$ świat uroczystych przez caly rok, $z$ Pisma Świętego i $z$ Doktorów Kościoła Powszechnego, $z$ wielka praca zebrany $i$ ku nauce wiernych chrześcijanskich ludzi $z$ pilnościa napisany [...]. Część pierwsza, od Adwentu do Wielkiejnocy, 
Kraków: Jan Januszowski, 1581, BJ Cim. 8061. Tekst skolacjonowano z: Marcin Białobrzeski, Kazanie o przyjmowaniu ciała i krwie Pana Jezu Krysta pod jedną osobą, Kraków: Andrzej Piotrkowczyk, 1579, BN. XVI.0.522adl.

\section{Zasady wydania}

1. Samogłoski. Druk postylli pochodzi z oficyny Łazarzowej, która wykazywała się starannością $\mathrm{w}$ redakcyjnym opracowaniu tekstów i stosowała oznaczenia samogłosek jasnych i pochylonych. $\mathrm{W}$ transkrypcji nie wprowadza się jednak rozróżnienia na $a$ jasne i pochylone, natomiast zachowuje się wszystkie oznaczenia kreskowania $o$ i $e$ za zabytkiem, by pokazać, na jakim etapie ścieśniania i pochylania długiego $o$ i $e$ znajdował się język polski pod koniec XVI wieku. Zachowuje się również formy wariantywne świadczące o procesie wyrównań analogicznych przegłosu polskiego: rzemieśle, świątości. Modernizuje się nieliczne przypadki braku nosowości w zaimkach osobowych i wyrazie zasię, aby zachować konsekwentnie to rozróżnienie, a także wariantywne i niekonsekwentne przypadki wtórnej nosowości; pozostawiono jedynie występujący konsekwentnie zapis zwolęnicy i męczęństwo. Zachowano również zapis miedzy - mimo że jego wtórna nosowość weszła do normy języka polskiego, tu jednak występował bez nosowości. Zmodernizowano zapis $y \mathrm{w}$ funkcji spójnika, $y$ przed spółgłoską $\mathrm{w}$ funkcji $i$ niezgłoskotwórczego, $y$ przed samogłoską transkrybuje się jako -ij lub $-y j$ : historyja, dyjakon. I w pozycji interwokalicznej oraz w nagłosie przed samogłoską oddaje się jako $j$. Zapis prziydzie transkrybuje się jako przyjdzie, boy jako boi, Anyoł jako anjoł, Chrześćiańskiey jako chrześcijańskiej. Nagłosowe $u$, zapisywane za pomocą litery $v$, zarówno majuskulne, jak i minuskulne, zmodernizowano do $u$.

2. Spółgłoski. Dźwięczność modernizuje się do współczesnej wymowy (np. rozprószca, różdżka), także w wypadkach bezdźwięcznych przed sonornymi, gdy ewentualne zachowanie bezdźwięczności byłoby słyszalne w realizacji dźwiękowej, jednak z uwagi na wariantywność i brak konsekwencji takiego zapisu (zmysty/smysty, smiłować/zmiłować) je również się modernizuje. Zlikwidowano znaki podwójnej 
miękkości (śi, ći, źi, dźi : si, ci, zi, dzi). Długie $\int$ transkrybowano jako $s$ lub ś, zgodnie z pisownią dzisiejszą ( iafny - jasny, iefli - jeśli). Wyrazy sftało (łac. fieri) i sftapił jako zstało, zstapit. W druku sporadycznie pojawiają się przypadki mazurzenia i szadzenia (cynit, czasz); zostały one zmodernizowane. Doprowadzono również do współczesnej wymowy wariantywny zapis $l / t$ (kaplaństwa, kazal, żalofné), a pozostawiono konsekwentny zapis naszladować. Zrezygnowano z zapisu miękkości $w(k r e w ́)$. Zmodernizowano pisownię małych i wielkich liter, a brak konsekwencji w zapisie kośćioł/Kośćioł rozwiązano, stosując współczesne rozróżnienie na kościół jako budynek i Kościół jako wspólnotę. Nazwy sakramentów zapisano małą literą, z wyjątkiem Komunii. Wielkie litery zastosowano we wszystkich formach wyrazów Bóg i Pan, gdy chodzi o Boga, oraz Mesyjasz, Dzień Święty (Pascha), Koncylijum (gdy chodzi o nazwę konkretnego soboru), Matka, Panna (gdy chodzi o Maryję), Doktor (gdy chodzi o tytuł doktora Kościoła w odróżnieniu od pospolitej nazwy uczonego) oraz w nazwach świąt i okresów liturgicznych - Wielki Post, Adwent. Pisownia nie z czasownikami, przysłówkami i przymiotnikami została uwspółcześniona (nie przepomniał, niemały). Partykuły -by, -byś, $-\dot{c},-\dot{s},-\dot{z},-\dot{z} e$ zapisano razem, zgodnie z dzisiejszą pisownią, partykuły - $l i \mathrm{i}$-ci natomiast rozłącznie $(i z \dot{z} c i, c z y l i)$. Zrosty pozostawiono zgodnie z zapisem $\mathrm{w}$ zabytku, $\mathrm{z}$ uszanowaniem wyczucia etymologicznego pisarza (dla tego w znaczeniu 'po to', niskąd inąd, Wielkąnoca). Zostawiono w formie stopnia najwyższego pierwotną grupę na (nawyższym), a także oboczność abo/albo, zmodernizowano podwojenie spółgłosek w wyrazie ossoba. Nazwy własne zasadniczo pozostawiono za zabytkiem jako świadectwo stopnia przyswojenia wyrazów obcych (Izraelite, Korynty). Uproszczono zapis th w wyrazach spolszczonych (katholic$k i$, kathedrze). Literę $x$ zastąpiono w wyrazach spolszczonych przez $k s$, z wyjątkiem tytułu dzieła Postylla ortodoxa, który zdążył się upowszechnić. $P h$ transkrybowano jako $f$. Skrót $s$. rozwinięto do święty (w zależności od użytego przypadka). Zachowano w całości końcówki i formy fleksyjne za przekazem jako świadectwo ówczesnego stanu językowego. 
3. Interpunkcja. Jeśli chodzi o interpunkcję, to $\mathrm{w}$ druku postylli Białobrzeskiego można spotkać trzy podstawowe znaki interpunkcyjne: ukośnik, dwukropek i kropkę. Rzadziej pojawia się pytajnik, średnik i nawias. Jest to sześć znaków opisanych przez Alda Manucjusza Młodszego w Ortographiae ratio, na której wzorował się Jan Januszowski. Podział tekstu za pomocą dwukropków i kropek w druku ma charakter retoryczny, dzieli tekst na periody, starano się zachować go przy użyciu średników, półpauz i kropek. Z kolei podział tekstu ukośnikami ma charakter bardziej logiczny - oddzielają one na przykład elementy wyliczeń, wtrącenia, proste przeciwstawienia. Ten podział starano się zmodernizować i oddać przy użyciu przecinków i dywizów. Cytaty najczęściej kończą się kropką, mimo że często po nich zdanie jest kontynuowane, zaznaczano je więc cudzysłowami, po których następują przewidziane w danym miejscu znaki przestankowe. Pozostawiono za przekazem znak akapitu g, który porządkuje tekst w podpunkty. 


\section{Kazanie o przyjmowaniu ciała i krwie Pana Jezu Krysta pod jedna osobą,}

ktoré to w sobie zamyka, jeśli z potrzeby zbawiennéj ma być przyjmowana dwoja osoba i dla czego pohamowana jest jedna osoba Sakramentu. Ewanjelija, która jest napisana przez Jana świętégo w kapitule $13^{19}$.

Wiadoma rzecz jest, że Pan Chrystus miedzy wielą dobrodziejstw swych, któré narodowi ludzkiému pokazać raczył, i to znaczné i wielkié dobrodziejstwo uczynił, iże pociechę nieosiérociałości wszytkim wiernym zostawił; i przeto Jan święty to u siebie uważając, tak pisze: „Chrystus Pan umiłował swé nie na czas krótki, Ioan. 13, ver. 1 ale prawie do końca umiłować je raczył". Lecz by spytał kto: „Czym je umiłować raczył?”. Tedy łatwie to umiłowanié każdy pokazać może, że niczym inszym, jedno wielkiémi swémi dobrodziejstwy, któré bez zasług naszych Pan nam uczynić raczył. Wielkieć dobrodziejstwo jest, że będąc w kształcie Bożym a wieczną formę Bożą na sobie mając, kształt człowieczy w wielkiéj pokorze przyjął; wielkié dobrodziejstwo jest, że z nas Bożych nieprzyjaciół - przyjacioły poczynił; wielkié dobrodziejstwo jest, że tajemnice wszytkié Ojca swego nam objawił - ale i to miedzy inémi wszytkimi nie pośledniejszé, gdy dla zbawienia naszégo ciérpieć miał, nas osiérociałémi nie zostawił, a wiedząc, że chléb, którégo w pracy sie dorabiamy, jest chléb boleści, tedy na pociechę każdému wiernému swemu zostawił chléb radości, który by nie tylko ciało posilał, ale i duszę od

Philip. 2, ver. 6

Roma. 5 , ver. 10

Ioan. 15 , ver. 15

Ioan. 14 , ver. 18

Pan Chrystus ciało swe dał na pociechę wiernym.

19 Por. opis ostatniej wieczerzy - J 13,1-38. Zgodnie w ówczesną praktyką kaznodziejską Białobrzeski najprawdopodobniej tłumaczył wszystkie cytaty z Pisma samodzielnie. 
Ioan. 6, ver. 49

Ioan. 6 , ver. 51

Ioan. 13 , ver. 1

Psal. 71, ver. 16

Ziścił kapłaństwo Melchizedekowe. wiecznéj śmierci wedle obietnice jego zachowywał. Toć jest wypełnienié onéj obietnice, którą Pan do tłuszczéj żydowskiéj mowić raczył: „Ojcowie waszy jedli mannę na puszczéj, a przedsię pomarli”. Obiecał tedy Pan już nie chléb łez i boleści, ale chléb wiecznégo żywota, gdy mówił: „Chléb ten, który ja wam dam, ciało moje jest, ktoré ja dam za żywot wszytkiégo świata”. Masz tedy, chrześcijański człowiecze, poznać to wielkié dobrodziejstwo Pańskié, bo coć obiecał, toć ziścił, a ziścił w ten czas, jako ewanjelista powiada: „Przed onym Dniem Wielkonocnym, kiedy wiedział Pan, że godzina jego już przychodziła, aby przeszedł $\mathrm{z}$ tego świata do Ojca”.

Abowiém tam wieczerzą uczyniwszy, obiecany chléb żywota nam wiernym swym zostawić raczył i ziścił w tym ono proroctwo Dawida świętégo: „Będzie zboże na ziemi, zrodzi sie na wysokich pagórkach, będzie przeniesion nad wszytki Libany owoc jego, a będzie z miast kwitnął jako kwiatki polné". Toć to zboże jest to, jako i żydowscy rabinowie ukazują, któré Mesyjasz przyszły na wszytkich miejscach tak górzystych, jako i równych, tak we wsiach, jako i w miastach zostawić miał, a prawdziwie sam siebie $\mathrm{w}$ tym to chlebie tego zboża wszytkim wiernym swym użyczyć ku używaniu miał. Tenże Mesyjasz nie tylo swą bytność miedzy ludźmi zostawić, ale téż i kapłaństwo ono wieczné wedle porządku Melchizedekowégo ${ }^{20}$ miał postanowić, i sam miał zostać tym, którému by ofiarowano - miał zostać tąż Ofiarą i tym jest, bo on jest ustawcą kapłaństwa, także i ofiary, i tym jest, komu ofiarują. Nie tylo tedy, że

20 Melchizedek - kananejski król i kapłan, wyszedł na spotkanie Abrama po jego zwycięstwie nad koalicją państw mezopotamskich, niosąc dar chleba i wina; był on ukazywany jako idealny kapłan i zapowiedź ofiary eucharystycznej (Ps 110,4). 
sie Kapłanem zstał w tym chlebie nad wszytki rzeczy wysokié wywyższonym, ale i tóż kapłaństwo postanowiwszy, choć mu tę ofiarę ofiarują, on jest przedsię tego kapłaństwa przednim i nawyższym Kapłanem.

g Dwoje tedy dobrodziejstwo na jednéj wieczerzéj nam zostawić raczyl:

Naprzód, że sie zstał Kapłanem naszym wiecznym, zstał sie Ofiarą naszą niekrwawą wieczną, zstał sie Jednaczem do Boga Ojca wiecznym.

Nauczył téż nas, jako jego kapłaństwo nie w ofiarach ani we krwi bydlęcéj, ale w chlebie i w winie jest i ma być zachowané aż na wieki, bo taki odnosi tytuł od proroka: „Ty jesteś kapłan na wieki, wedle porządku Melchizedeka", w którym to kapłaństwie tak sie Pan Bóg ukochać raczył, że ono kapłaństwo Aaronowé dla tego Mesyjaszowégo $\mathrm{z}$ lubości swéj zniósł, mówiąc przez proroka: „Nié mam ja z wami (do Żydów mówi) ani $\mathrm{w}$ was woléj mojéj i ofiary nie przyjmę z ręku waszych, abowiém od wschodu słóńca aż do zachodu wielkié jest imię moje miedzy pogany, przeto że imieniu mojemu na każdym miejscu będzie ofiarowana ofiara czysta”. Tęć Pan sobie wdzięczną ofiarę ukazać raczył, która nie w Jeruzalem, Kościele Salomonowym, ale po wszytkim świecie, a jakoś Dawida przed tym słyszał, po górach, po równiach, po wszytkich wysokich miejscach miała być ofiarowana, a nie ofiara chwały, ale ofiara, która nie sercu, ale miejscu przypisana jest, bo mówi: „Na każdym miejscu od wschodu słóńca aż do zachodu”. Ofiara tedy ta miała być więtsza i poważniejsza niż żydowskié ofiary, a zatym Panu Bogu milsza. Czemu? Daje Paweł święty przyczynę: że Mesyjasz Jezus Chrystus zstał sie Sprawcą lepszégo Testamentu, prze to że trwając na wieki, wiecznym jest Kapłanem i wiecznie zbawia. Lecz o kapłaństwie Chrystusowym żeśmy dostatecz-

Psal. 109, ver. 4

Malach. 1, ver. 10.

Kapłaństwo, któré jest

Panu Bogu po wszytkim świecie wdzięczné.

Hebrae. 7, ver. 22. Czemu to uczynił. 
Lucae 22, ver. 19;

1 Cor. 2 , ver. 24

Facere pro offerre.

Facere pro offerre.

Levit. 23, ver. 10;

Ezech. 45, ver. 20

et 46 , ver. 15

Kiedy to uczynił.

Ioan. 13 , ver. 3 ;

Psal. 40, ver. 10

Co nam dać raczył.

Aug[ustinus] in Psal[mum] 98

Matt. 26, ver. 26 nie $\mathrm{w}$ Katechizmie pisali ${ }^{21}$, tu daléj o nim mówić nie chcemy. Dosyć jest, żeśmy pokazali Chrysta Pana być wiecznym Kapłanem nie z strony tylko osoby jego, ale z strony kapłaństwa jego, $\mathrm{z}$ strony urzędu, który urząd nie tylo sam na sobie odniósł, ale i inszym w szafunek podał, gdy mówił: „To, com ja czynił teraz na wieczerzy swojéj, ilekroć czynić będziecie, na pamiątkę moję będziecie czynić"; nie tylko używać, ale téż i ofiarować, bo to słowo facere - to jest „czynić” - Pismo Święté wykłada, że sie ma rozumieć „ofiarować” ${ }^{22}$, jako o tym masz u proroków. Kiedyż tedy to Pan uczynić raczył, że sie Kapłanem zstał i kapłaństwo nowégo Testamentu nam zostawił? Jan święty w dzisiejszéj Ewanjelijéj powiada: w ten czas, kiedy sprawił wieczerzą, kiedy Ojciec niebieski dał mu wszytko w ręce i wiedząc, że poszedł z Boga i do Boga Ojca szedł, wiedząc téż, że sie ono Pismo już wypełnić miało - ten, który chléb z nim jadł, miał podniéść przeciwko niemu zdradę swą - $\mathrm{w}$ ten to czas i wieczné kapłaństwo nam zostawił, i pod osobą chleba i wina własné ciało swoje i kréw tak raczył postanowić, że, jako Augustyn święty daje o tym świadectwo, „sam siebie w rękach swych nosił, sam siebie zwolęnikom swym podawał"23. A by téż Augustyn święty tak jaśnie tego nie podał w wykładzie swym, tedy sam Pan Chrystus znacznie to pokazuje, że tak jest, gdy mówi: „Bierzcie, jédzcie, to jest ciało moje; bierzcie, pijcie, to

21 Por. M. Białobrzeski, Katechizm albo Wizerunk prawej wiary chrześcijańskiej [...], [b.m.w.] 1567, s. 285, 293, 341-343.

22 Argumentacja filologiczna ukazująca Mszę jako ofiarę jest śladem polemiki z tymi, którzy za jedyną ofiarę uważali wyłącznie tę złożoną przez Chrystusa i którzy przeczyli temu, aby w Eucharystii wierni mieli udział w tej ofierze.

23 Swięty Augustyn, komentarz do Psalmu 33: „Nosił to ciało w swoich własnych rękach" (św. Augustyn, Objaśnienia Psalmów. Ps 1-36, przeł. i wstęp J. Sulowski, oprac. E. Stanula, Warszawa 1986, s. 330). 
jest krew moja”. Toć każdému znaczna rzecz być może i jasna, żeć nie co inszégo, jedno swé ciało własné pod osobą chleba im podawał. I przeto tenże Augustyn święty, temu sie dobrze przypatrzywszy, tak o tym swé wyznanie dał: „Ciało, ktoré Chrystus Pan z czystéj Panny wziął, tóż nam ciało ku używaniu dał"24.

g Bylić kafarnaite ${ }^{25}$, są i po dziś dzień, którzy na kształt przodków swoich mówią: „Jako to być może? Jako nam może dać ciało swé ku jedzeniu? Twarda to mowa" ${ }^{26}$. I jać tak powiadam tobie, że twarda. Ale pytasz, komu twarda? Czy apostołom? Czy kafarnaitom? Czy wiernym Chrystusowym? Czy niewiernym? Wiernym nie twarda to mowa, bo mówią $z$ apostoły: „Panie, słowa wiecznégo żywota masz, nie jest tobie nic niepodobnégo, słowa twoje duch i żywot są, nie pójdziem od ciebie, nie odwrócim sie od słów twoich, będziemy im wierzyć, boś ty jest prawda, będziemy ich słuchać, bo wiémy, iżeś mistrz prawdziwy i drógi zbawiennéj prawdziwie uczysz". Niewiernym tedy kafarnaitom i ich naszladówcom, sakramentarzom, kalwinistom, zwinglijanom ${ }^{27}$ twardé to słowa, prze to iż nie chcą zniewolić rozumu swego pod posłuszeństwo wiary. Nie kafarna-

Ioan. 6 , ver. 68 ; ibidem, ver. 63

Ioan. 14 , ver. 6 ; Matt. 22, ver. 16

2 Cor. 10 , ver. 5 itom tedy, ale wiernym Pańskim własną bytność ciała

24 Ibidem.

25 Kafarnaici zakładali, że w Eucharystii spożywa się ciało Chrystusa w rozumieniu biologicznym; nazwani tak od pytania, które Żydzi zadawali sobie w Kafarnaum: „Jak On może nam dać swoje ciało do jedzenia?” (J 6,52).

26 Aluzja do J 6,60: „Twarda jest ta mowa; i któż jej słuchać może?”, Biblia w przekładzie księdza Jakuba Wujka z 1599 r., transkrypcja typu „B” oryginalnego tekstu z XVI w. i wstępy J. Frankowski, Warszawa 1999.

${ }_{27}$ Sakramentarzom... - zaprzeczającym rzeczywistej obecności Jezusa w Eucharystii; byli to przede wszystkim Ulrich Zwingli, Andreas Karlstadt i Jan Oekolampad; wszyscy członkowie wymienionych grup nie uznawali substancjalnej obecności ciała Chrystusa w Eucharystii. 
Dlaczego Pan pod osobami chleba i wina zostawić raczył ciało i krew.

I. Dla siebie.

Ioan. 15 , ver. 9 ; ibidem, ver. 4

Psal. 110, ver. 4

Pańskiégo pod osobami widomémi dowodzić będziemy, którą bytność jako zostawił Pan pod osobą chleba i wina, słowa wieczerzéj Pańskiéj uczą.

Ale by pytał: „Dlaczego Pan pod témi osobami, a nie pod inszémi to używanié ciała i krwie swéj zostawić raczył?" Są tego pewné i słuszné przyczyny. A iż je potrzeba człowiekowi chrześcijańskiému wiedzieć, pokażemy je co nakrócéj.

g Naprzód uczynił to dla siebie, Pan, potym dla nas. Chciał Pan w takich rzeczach postanowić ustawę swoję, któré są napospolitszé na świecie i przez których żywot człowieczy być nie może, aby sie żaden nie wymówił albo niepodobnością, albo jaką nieznajomością niezwykłych żywiołów, abowiém wszyscy bez chleba obyść sie nie mogą, każdy go zna, każdy sie oń stara.

Ale jakóż to Pan dla siebie postanowić raczył? Atoć powiem: żeby nigdy nie ustała miłość jego w nas, a jeśliby zagasła, aby sie często rozżarzała i ponawiała - tedy dla tego pod osobą chleba i wina ${ }^{28}$ zostawił nam Pan ciało i kréw swoję, czego sie uczyć możesz z onéj Pańskiéj wieczerzéj.

Dawa Pan pod widomémi znaki ciało swé niewidomie, a prawie po podawaniu mówi: „Mieszkajcie w miłości mojéj, mieszkajcie we mnie, a ja w was będę; bo jako różdżka nie może pożytku dać, aż mieszka w macicy $^{29}$, tak i wy pożytku nie dacie, aż we mnie będziecie mieszkać”. A iż takim w miłości Pana Chrystusowéj i w miłości zobopolnéj pokarm swój ten zostawić raczył, było o tym dawno proroctwo: „Uczynił Pan cudów swoich pamiątkę w tym, że pokarm dał onym, którzy

28 Białobrzeski różnie nazywa obie postacie sakramentu: „osoby”, „znaki”, „elementa”, „figury”.

29 Tzn. w głównej gałęzi, łodydze krzewu winnego. 
sie go boją". Bojaźń tu synowską, która z miłości pochodzi, prorok rozumiał - tedy takich pokarm ten jest, którzy Pana Chrystusa miłują i boją sie go jako ojca łaskawégo, aby go nie rozgniewali. Obyczaj miłości i wizerunk prawdziwy Jan święty opisuje, gdy Pańskié słowa powiada: „Jeśli mię kto miłuje (Pan mówi), mowę moję będzie chował” i na drugim miejscu: „Który ma przykazanié moje a chowa je - to jest wypełnia - ten jest, który mię miłuje”. Dla miłości tedy Pańskiéj, aby $\mathrm{w}$ nas trwała, aby sie często ponawiała, mamy tę ustawę nam zostawióną.

g Nadto żeby pamiątka męki jego i opowiedanié niewinnéj śmierci jego w nas nigdy nie zagasła, dla tego to sie zstało przez Pana, co pokazując Paweł święty, mówi: „Ilekroć będziecie jeść chléb ten i kielich pić, śmierć Pańską rozgłaszać będziecie tak długo, aż przyjdzie”. Uczy Paweł święty rozgłaszać śmierć Pańską - to jest wyznawać to jaśnie, że dla grzéchów naszych umarł, niewinny dla winnych - i za to mu cześć i chwałę czynić nie tylko usty mówiąc, sercem dziękując, ale chleba i kielicha używając.

g Trzecia jeszcze przyczyna postanowienia pod widomémi osobami ciała i krwie Pańskiéj jest ta, aby przez to używanié do duchownégo ciała Chrysta Pana przyłączeni byliśmy; iż jako przez grzéch na krzcie wziętą łaskę Bożą tracimy i z ciała Pana Chrystusowégo - to jest z Kościoła jego powszechnégo, którégo on jest głową - odpadamy - tak zasię przez przyjęcié niewinnégo ciała Pana Chrystusowégo w zbór chrześcijańskiégo Kościoła byliśmy wszczépieni, bo przystępując do tego ciała niewinnégo naszé winné ciało ma być doświadczoné i przepolerowané upamiętanim, pokutą i rozgrzeszénim. Toć jest, co Paweł święty rozkazuje: „Niechaj sam siebie doświadczy człowiek, a tak doświadczywszy sie, z onégo chleba i z onégo kielicha nie-

Dla przyłączenia do duchownégo ciała Pana Chrystusa.

1 Cor. 2 , ver. 28
Ioan 14, ver. 23

Ibidem, ver. 21

1 Cor. 2 , ver. 26 
Swoboda od szatana

i piekła.

Exodi 12, ver. 14

1 Cor. 10 , ver. 17 chaj używa, bowiem który by niegodnie tych znaków zwiérzchnich używał, będzie winien ciału i krwi Pana a Zbawiciela swego". Téć są przyczyny ustawy Pańskiéj z stróny Pana Chrystusa.

Z stróny potrzeby naszéj są wielkié przyczyny, a miedzy inszémi ta jest najpiérwsza: bo iż figurom wszytkim starégo Zakonu istota $\mathrm{u}$ nas $\mathrm{w}$ nowym Zakonie wykonać sie miała, przeto i figura wybawienia Żydów z Egiptu, którą baranek wielkonocny znaczyl, wybawienié z niewoléj szatańskiéj w nas ziścić sie miała - otóż jako baranka Żydowie pożywali na pamiątkę wyszcia z niewoléj egiptskiéj, tak téż i my mamy tego Sakramentu używać na pamiątkę wyswobodzenia nas z niewoléj piekielnéj przez śmierć Pana Chrystusowę. Wielkać to przyczyna. Ale jeszcze więtszą pokażę, która snadź, jeśli Doktorom świętym wierzymy ${ }^{30}$, więtsza jest aniż przyjmowanié osob widomych. Ta jest tedy nawiętsza przyczyna przyjmowania ciała Pańskiégo pod osobą chleba i wina: zostawienié miłości, życzliwości i sprzyjazności chrześcijańskiéj. Nie darmoć w starożytnym Kościele tę świątość zwano hasłem chrześcijańskiéj miłości i życzliwości, nie darmo i Paweł święty to pokazując, tak mówi: „Jeden chléb, jedno ciało jesteśmy, choć nas

${ }^{30}$ Już św. Ignacy Antiocheński, uczeń św. Jana, był orędownikiem jedności Kościoła: „Starajcie się zatem uczestniczyć w jednej Eucharystii. Jedno bowiem jest Ciało Pana naszego, Jezusa Chrystusa i jeden kielich, by nas zjednoczyć z Krwią Jego, jeden ołtarz, jak też jeden biskup razem z kapłanami i diakonami", św. Ignacy Antiocheński, List do Kościoła w Filadelfii, w: Eucharystia pierwszych chrześcijan. Ojcowie Kościoła nauczaja o Eucharystii, wybór i oprac. M. Starowieyski, wstęp M. Starowieyski, J. Miazek, A. Luft, Kraków 2014, s. 58. Podobnie św. Augustyn: O Sacramentum pietatis! O signum vitalis! O vinculum charitatis! (O Sakramencie pobożności! O życiodajny znaku! O więzi miłości!), In Joannis Evangelium tractatus CXXIV, w: Patrologiae cursus completus. Series latina, ed. J.P. Migne, 35, 1613 [dalej PL], przekład własny. 
jest wiele, przedsię jednak wszyscy jedno jesteśmy, którzy z jednégo chleba i z jednégo kielicha pożywamy”. Piękné przystosowanié Pawła świętégo jednégo ciała $\mathrm{z}$ wielą rozlicznych członków do jednégo chleba, który jest $\mathrm{z}$ wiela ziarn upieczony, i do wina, ktoré jest $\mathrm{z}$ wiela gron wyciśnioné, bo jako $\mathrm{z}$ wielości materyj chléb i wino jest jedna istota, tak $\mathrm{z}$ wiela członków jest jedno ciało. Otóż jako w ciele jednym wszytki sie członki szanują i miłują, tak w żywiołach chleba i wina wielość materyj człowiekowi smak podając, zgodę miedzy sobą czynią. [...]

Tuć by było szérokié miejsce was napomniéć, chrześcijanie, o spółecznéj życzliwości chrześcijańskiéj, lecz iż Jan święty, apostół i ewanjelista, krótko to rozprawił, co to jest za rzecz wielka jeden drugiégo przed Panem Bogiem miłować, na jego wyroku przestawszy, jegóż nauki słuchajcie: „Kto mówi, że Pana Boga miłuje, a brata swego - to jest chrześcijanina - ma w nienawiści, kłamca jest; i kto w nienawiści ma brata - to jest człowieka chrześcijańskiégo - zabijacz jest ludzki”. Tu masz życzliwości chrześcijańskiéj krótką naukę, jako sie ma zachować i jako poważna jest u Pana Boga życzliwość miłości chrześcijańskiéj.

Ale sie podziwujmy wszyscy, co sie zstało: miłość nade wszytko Jezus Chrystus, Syn Boga żywégo, Pan a Zbawiciél nasz nam zaleca, tę nam usilnie rozkazuje, dla téj nam pozostawił pod widomémi znaki ciało swé cóż sie zstało, że miedzy chrześcijany namniéj miłości zostało? I co im nabarziéj rozkazano, o to namniéj dbają, tak że i pogani a bluźniércy Syna Bożégo przewyższają chrześcijany w miłości i w życzliwości jeden przeciwko drugiému. Dobreć to było nasienié Chrysta Pana, ktoré tłumiło i słabym czyniło królestwo szatańskié, lecz nieprzyjaciél człowieczy szatan tak okrutnie z kąkolem swym pośniécił, że mało téj dobréj pszenice kąkolem nie

Co Pan nawięcej rozkazuje, tego namniej miedzy chrześcijany. 
zarościłำ bo i to hasło miłości chrześcijańskiéj, skąd zgody i życzliwości Sakrament ciała Pańskiégo naświętszy do takiégo roztargnienia przywiódł, że czymeśmy sie jednoczyć mieli, tym nas we Zborze chrześcijańskim rozerwał, roztargał, w miłości pomiészał, uczyniwszy z miłości nieukojoną niezgodę, nieuśmiérzony niepokój, nienawiść nigdy niepohamowaną. Co jaki żal, kto to przypuści do serca, jaki smutek ludziem chrześcijańskim, którzy miłości i jedności w chrześcijaństwie pragną, dowodzić nie trzeba - żałosné serca prawdziwych chrześcijan ustawicznie to czują.

Ale żebyś, chrześcijański człowiecze, obaczył, jako

Pokazuje jako sie zstała niezgoda z strony Sakramentu.

$\mathrm{Z}$ używania kwaszonégo i przasznégo. on wąż, czart stary, w tym tu naświętszym Sakramentcie nas do niezgody przywiódł i rozerwał do nieuspokojonéj nienawiści, tak ci pokazuję. Trzy rzeczy szatan wrzucił miedzy ludzie chrześcijańskié, aby w podawaniu ciała Pańskiégo Sakramentu zgodni nie byli:

I Naprzód około chleba uczynił rozerwaniés2, iż jedni w kwaszonym, a drudzy w przaśnym prawdziwéj bytności i własności ciała Pańskiégo pożywają. Toć uczyniło rozerwanie i wieczną a nieuspokojoną nienawiść miedzy greckim a łacińskim Kościołem i z jednégo Kościoła Chrysta Pana dwa uczyniło. Czemu jaką przyczynę szatan dał, krótko pokażę.

Wzbudził czart nieprzyjaciela Chrysta Pana, kacérza Ebijona $^{33}$, który aby lud chrześcijański do żydostwa i ich

31 Mt 13,24-40.

32 Jedną z bezpośrednich przyczyn schizmy wschodniej (1054) był spór o używanie niekwaszonego chleba do konsekracji na Zachodzie, co było przez Wschód uznawane za niezgodne $\mathrm{z}$ Tradycją.

33 Ebionici nie zgodzili się $\mathrm{z}$ postanowieniami zapadłymi na soborze jerozolimskim, zwalniającymi nowo ochrzczonych z przestrzegania nakazów żydowskiego Prawa. Białobrzeski zakłada etymologiczne pochodzenie ich nazwy od założyciela, podobnie jak stało się w przypadku arian, historyczne istnienie Ebiona 
cerymonij prędzéj przyłudził, tym je przysmakiem łowił: że jeśli w co naprzedniejszym Sakramencie obyczajem żydowskim lud chrześcijański podanié Pana Chrystusowo wypełnia, słusznie tedy i w inszych rzeczach Zakonu starégo cerymonij, obrządków, ofiar, obrzezania i inszych rzeczy naszladować ma, gdyż i Pan Chrystus obrzezaniém, ofiarowaniém, Wielkąnocą nie tylo, że sie nie obrzydzil, ale i dostatecznie to w sobie wypełnił, a na ostatek i ciało swé pod sprawą i porządkiem Wielkiéjnocy żydowskiéj wszystkim chrześcijanom zostawił - i przetóż powiedał, że nie przyszedł Chrystus Pan psować Zakonu starégo, ale wypełniać. A jeśli go Chrystus wypełniał, w nim tajemnice ciała swego własnégo zostawił - czemu chrześcijanie mają być od niego próżni? Taką farbiczką rumienił tę swą posiniałą naukę zły kacérz Ebijon, nie pamiętając na apostolskié pisma i ich rozkazania, którzy nie chcieli tego brzemienia Zakonu starégo kłaść na chrześcijany. Lecz iż szatan jad ten swój przez Ebijona, a więcéj przez ucznie jego, tak był hojnie na świecie rozsiał miedzy chrześcijany, że sie ich wiele w żydostwo obracało, a razem i Żydy, i chrześcijany być chcieli, a nie przez żaden inszy przysmak, jedno przez niekwaszony chléb, w ktorym używali chrześcijanie ciała Pańskiégo - tedy pastérz widomy Kościoła Bożégo, biskup rzymski, wszytkiemu Kościołowi chrześcijańskiému pokój chcąc uczynić, błąd chcąc wyniszczyć i uśmiérzyć, postanowił, aby wszyscy chrześcijanie po wszystkim świecie w kwaszonym chlebie ciała Pańskiégo używali, jako o tym pisze Leo Papa ad Epi-

jest jednak podawane w wątpliwość, a nazwa „ebionici” wywodzi się od hebrajskiego ebjonim - „ubodzy”. 
scopos Syriae, Epistola $41^{34}$. Trwała tedy ta ustawa długi czas w powszechnym Kościele, aż kiedy błąd, przyczyny nie mając do zwodzenia ludzkiégo, ustał, tedy téż zasię własną Pańską sprawę wieczerzéj czynienia Kościołowi z téjże zwierzchniéj stolice przywrócono - przystali i wrócili sie do niekwaszonégo chleba łacinnicy, a grekowie przystać już nie chcieli i przy kwaszonym chlebie zostali, i choć jednako służy poświęcenié kwaszonému, jako i niekwaszonému chlebu, i tak moc słów Pańskich w kwaszonym, jako i w niekwaszonym własność ciała Pańskiégo sprawuje, i choć to grekom i ich naszladówcom pokazano dosyć dostatecznie na Koncylijach Florenckim i Laterańskim ${ }^{35}$, przedsię jednak zgody i jedności onéj piérwszéj nie uczyniono, ani do niéj i do tego czasu jeden Kościół Chrystusów przyść może. Toć jest najpiérwszé rozérwanié chrześcijanów z przyczyny chleba.

g Ale jużże szatan przestał na tym piérwszym swym

Wtóré rozerwanié z strony używania Sakramentu. rzemieśle, kiedy wschód słońca od zachodu w jedności chrześcijańskiéj rozerwał? Chytry wąż nie przestał na

34 List 41 papieża Leona IV (1 poł. IX w.) do Ignacego, patriarchy Konstantynopola.

35 Sobór Laterański IV (1215) przyjął dogmat o transsubstancjacji: „Jego ciało i krew prawdziwie zawarte są w sakramencie ołtarza pod postaciami chleba i wina, przeistoczonymi mocą Bożą: chleb w Ciało, wino w Krew", Innocenty III, Zwołanie soboru powszechnego, w: Dokumenty soborów powszechnych. Tekst grecki, łaciński, polski, t. 2: Konstantynopol IV, Lateran I, Lateran II, Lateran III, Lateran IV, Lyon I, Lyon II, Vienne (869-1312), układ i oprac. A. Baron, H. Pietras, [przeł. A. Baron et al.], Kraków 2003, s. 215. Sobór Florencki orzekł 6 lipca 1439 roku, „że ciało Chrystusa prawdziwie jest sprawowane w chlebie pszenicznym, przaśnym bądź zakwaszonym. Kapłani powinni sprawować ciało Pana używając jednego z nich, każdy według zwyczaju swego Kościoła, zachodniego lub wschodniego", Bulla unii $z$ Grekami, 13, w: Dokumenty soborów powszechnych. Tekst łaciński, grecki, arabski, ormiański, polski, t. 3: (1414-1445) Konstancja, Bazylea-Ferrara-Florencja-Rzym, układ i oprac. A. Baron, H. Pietras, [przeł. A. Baron et al.], Kraków 2003, s. 471. 
tym, bo na zachód słońca miedzy zgodliwymi chrześcijany tak wielką niezgodę i nienawiść rozsiał, że sie jeden drugim jako parszywą owcą brzydzi dla tego świętégo Sakramentu - bo wnet kiedy obaczył, że zgodliwie na przaśnym chlebie przestali, wnet jął bytność własną ciała Pańskiégo pod osobami widomémi $\mathrm{z}$ wiary ludzkiéj plewić i gładzić, oné Pańskié słowa szczéré i prawdziwé „to jest ciało moje” rozmaicie mozgiem ludzkim nicując i w nich wielką wątpliwość czyniąc. Bo:

Jedny pobudził, aby wykładali: to jest figura ciała mego.

Drugie, aby mówili: to jest upominek ciała mojego.

Trzecié, aby uczyli: to jest znak ciała mego.

Czwarté: tu jest w chlebie ciało moje.

Piąté: tu jest przy chlebie ciało moje ${ }^{36}$.

I inszych wykładów dosyć hojnie po wszytkim chrześcijaństwie nasiał i namnożył. Przypatrzże sie, jaka nieprzyjaźń, jaka niezgoda jest miedzy témi, którzy szczérze i prosto wierzą tym słowom Pana Chrystusowym „to jest ciało moje”, a miedzy onémi, którzy je tak sprośnie nicując, wedle lubości swéj wykładają, tak że sie i sami od nas odłączywszy, szwermerami ${ }^{37}$, war-

36 Słowa „To jest Ciało moje” interpretuje się zasadniczo na dwa sposoby: pierwszy to interpretacja anamnetyczna, czysto obrzędowa, w pierwszych wiekach chrześcijaństwa doktorzy Kościoła w nauczaniu kładli nacisk na znakowość sakramentu, a byli to m.in. św. Ignacy Antiocheński, Tertulian, św. Ireneusz, św. Augustyn; drugi sposób to interpretacja historiozbawcza, realistyczna, misteryjna, występująca w postaci teorii impanacji (wchlebienia) lub w postaci konsubstancjacji. Reformatorzy odrzucili interpretacje realistyczne, i tak Luter twierdził, że impanacja występuje, ale tylko w momencie wykonywania czynności liturgicznej, potem chleb jest tylko znakiem; Zwingli uczył, że Chrystus jest obecny jako znak, pamiątka; Kalwin - że Chrystus jest obecny tylko przez swą moc, a nie przez byt.

${ }_{37}$ Szwermer - od niem. Schwärmerei, 'marzyciel'; określenie używane przez Lutra na tych, którzy nie uznają rzeczywistej obecności Chrystusa w Komunii (Kasper Schwenckfeld, Ulrich Zwingli). 
Trzecia przyczyna niezgody z strony Sakramentu. tołbami ${ }^{38}$ szalonymi jaśnie sie zową. Chcesz wiedziéć przyczynę? A to Sakrament jedności i zgody z zazdrości szatańskiéj, z niespokojnych rozumów (nie z strony siebie) uczynił przyczynę.

I A jużże tu koniec? Nie uspokoił sie jeszcze szatan, bo kiedy obaczył zgodę w wierze onych chrześcijanów, którzy własną bytność (słowom Pańskim wierząc) ciała Pana Chrystusowégo pod osobami widomémi wierzyli, wnet wzbudził Nestoryjusza ${ }^{39}$, nieprzyjaciela bostwa Pana Chrystusowégo, który pod osobą chleba martwé ciało na krzyżu wysuszoné, pod osobą wina krew wytoczoną uczył być i tak wierzyć rozkazował. Stąd tedy już około używania ciała Pańskiégo począł sie przez tego to kacérza i jego ucznie w chrześcijaństwie wielki błąd rozmnażać, gdy osobno ciało, osobno krew dzielić począł. Czemu wszytkiému Kościół święty zabiégając, starał sie o takié lékarstwo, aby szatanowi to pokazał, że Pan Chrystus zupełny jest pod obiema osoboma - to jest że pod osobą chleba nie umarłé ani na krzyżu wysuszoné ciało, ale żywé i prawdziwé ciało jego jest; tak-że téż pod osobą wina nie ona krew od ciała odłączona, ale krew żywégo ciała Pana Chrystusowégo prawdziwa jest - co Kościół święty w onym pieniu tak wyznawa:

Pod różnémi osobami,

Nie cieleśnie, lecz znakami.

Zakryté tajemnice

Ciała i krwie używania,

Zupełnégo Chrysta brania

Pod dwiema osoboma ${ }^{40}$.

38 Wartołeb - impulsywny, szybko (wartko) myślący.

39 Nestoriusz (V w.) - patriarcha Konstantynopola, twórca doktryny o rozdzielności boskiej i ludzkiej natury Chrystusa, zwanej nestorianizmem.

40 Pieśń eucharystyczna, będąca tłumaczeniem łacińskiej sekwencji Lauda Sion, napisanej przez św. Tomasza z Akwinu ok. 1264 roku; jej siódma zwrotka brzmi: 
To jest: równie pod osobą chleba, jako i pod osobą wina, pod obiema osoboma zupełny jest Chrystus, żywé ciało jego i krew, zupełné bostwo, on jeden Chrystus, który jest Bóg i człowiek.

Tuć już nam przyjdzie mówić o tym, jeśli z potrzeby zbawiennéj ma człowiek chrześcijański pożywać pod dwiema osoboma. Ci, którzy téj nauki uczą, że powinien każdy pod dwiema osoboma używać, tak powiedają, że mają Pismo po sobie, bo powszechné rozkazanié być uczą $\mathrm{w}$ onych słowiéch u Jana świętégo: „Jeśli nie będziecie pożywać ciała mego i nie będziecie pić krwie mojéj, nie będziecie mieć żywota w sobie, bo ciało moje jest prawdziwy pokarm, a krew moja jest prawdziwy napój”. Powiedają téż, że Pan Chrystus tak postanowił i tak rozdawał pod dwiema osoboma, tedy i my wszyscy wierni jego wedle postanowienia Pańskiégo brać i przyjmować mamy. Po trzecié uczą, że Chrystus wszytkim a wszytkim kazał tak brać, gdy mówił: „Pijcie $\mathrm{z}$ tego wszyscy", kielich podając apostołom. Toć są wszytki potężné dowody, a jakoby jakié mocné katapulty i tarany, którymi jedność chrześcijańską, miłość i życzliwość zobopólną psują, niszczą i wygładzają. Ale iż o osoby napiérwéj idzie (osoby zowie widomé żywioły chleba i wina), tedy naprzód pokazać to musimy, co są osoby

O osobach naukę naprzód ukazuje. Sakramentu, a co moc i istota ich i w czym zależą.

Sub divérsis speciébus,

Signis tantum, et non rebus,

Latent res exímiæ.

Caro cibus, sanguis potus:

Manet tamen Christus totus,

Sub utraque specie (In solemnitate Corporis Christi, w: Missale Romanum, ex decreto Sacrosancti Concilii [...], Würzburg: Johann Hertz, 1698, s. 354). 
Psal. 83, ver. 12

1 Cor. 12 , ver. 6

Matt. 26, ver. 28

Lib. 4, epist. 7

Potrzebné elementa do wiary być ukazuje.

I Naprzód tedy każdy chrześsijański człowiek ma wiedziéć, że zwiérzchnié znaki, w których istoty ciała Pańskiégo tajemnéj używamy, nie są takiéj powagi, aby łaskę Bożą, żywot wieczny w sobie tak miały, żeby za ich używaniém już to z powinności człowiek sobie otrzymał - znaczą oné tylko łaskę Bożą, ale jéj nie dawają; bo tak Pismo Święté świadczy: „Łaskę i chwałę Pan Bóg daje” i Paweł święty: „Pan Bóg sprawuje wszytko we wszytkich". A iż zwiérzchnie té żywioły znaczą albo znak łaski Bożéj tylko na sobie odnoszą, tego ten jest dowód: bo kiedy żywioł chleba i żywioł wina przyjmujemy, nic tam inszégo nie rozumiémy, jedno to, że Pan Chrystus ciało i krew dla naszégo zbawienia wydać raczył. Ale wszytka moc zbawienia należy w onéj prawdziwéj wierze, którą wierzymy słowom Pańskim, że ono jest prawdziwé ciało, któré za nas i za wszytek świat jest wydané, i krew prawdziwa, która dla odkupienia grzéchów naszych jest przelana. Ta wiara u Pana Boga daleko więtsza jest i przyjemniejsza aniż osoby Sakramentu, gdyż rzeczom zwiérzchnim nie jest przywiązana łaska miłégo Boga, jako świadczy Cypryjan święty ${ }^{41}$, i przeto wiarą niewidomé a prawdziwé ciało Pańskié bywa przyjmowané i wiarą wszytki obietnice Pańskié wiernym Pana Chrystusowym bywają wykonané.

g Lecz aby kto nie rozumiał, żeby widomé elementa do wiary chrześcijańskiéj niepotrzebné miały być,

${ }^{41}$ Święty Cyprian (III w.), biskup, apologeta i męczennik, sprostował błąd, który wkradł się do praktyki Kościoła, a który polegał na konsekracji samej wody. O znaczeniu materii w sakramencie pisał: „iż słowo «woda» zawsze chrzest oznacza i że tak winniśmy ją pojmować. Pan przez swoje przyjście podał prawdziwe znaczenie chrztu i kielicha; wody życia wiecznego kazał wierzącym przy chrzcie udzielać; co do kielicha, to pouczył swym nauczycielskim przykładem, że winien być napełniony mieszaniną wina i wody", św. Cyprian, Listy, przeł. W. Szołdrski, Warszawa 1969, s. 207. 
damy przyczyny, dla czego ich wzgardzać nie mamy. Zeznawam, że zwierzchnie znaki przez sie znaki tylo są i dla tego od Doktorów Kościoła chrześcijańskiégo nazwané są figurami, osobami zwiérzchnimi, świętéj rzeczy znakami, chlebem, winem. To aby prawda była, Augustyn święty jest świadek ${ }^{42}$, który mówi: „Sakrament ciała Pańskiégo ze dwu rzeczy jest: $\mathrm{z}$ widomych znaków i z niewidomégo ciała Pana Chrysta i ze krwie jego”; i tenże na drugim miejscu: „Ciało Pana Chrystusowé i prawdą, i figurą jest - prawdą, kiedy ciało i krew Pana Chrystusa w słowie jego sprawą Ducha Świętégo $\mathrm{w}$ istocie chleba i wina stawa sie, a figurą jest $\mathrm{w}$ tym, co oczy naszé widzą i na co patrzają".

Przeto każdy chrześcijański człowiek té trzy rzeczy baczyć ma w Sakramentcie ciała Pańskiégo ${ }^{43}$ :

Bernardus, serm. 2 de Coena Domini

Osobę chleba i wina;

Prawdę zupełną istotnégo i własnégo ciała Pańskiégo;

Moc łaski dusznéj, ktorą z obietnic swych Pan Chrystus dawać raczy.

Osobę chleba oko człowieczé cieleśnie widzi, ogień kazi, robak toczy, starość niszczy; prawdę istotnégo i własnégo ciała Pańskiégo wiara i oczy duszné wierzą i widzą - a moc łaski Bożéj w duszach naszych i ożywie-

42 Święty Augustyn zaczął zacieśniać terminy mysterium i sacramentum do liturgii i sakramentów w rozumieniu dzisiejszym. W traktacie O państwie Bożym (X 5, 10) wprowadził też definicję sakramentu, który jest „znakiem świętym niewidzialnej ofiary odkupieńczej" (Invisibilis sacrificii sacramentum id est sacrum signum), św. Augustyn, O państwie Bożym. Przeciw poganom ksiag XXII, przeł. i oprac. W. Kornatowski, Warszawa 1977, t. 1, s. 447. O obecności Chrystusa pod znakami chleba i wina św. Augustyn pisze jeszcze w De doctrina christiana. O nauce chrześcijańskiej (III, 13; przeł., wstęp i oprac. J. Sulowski, Warszawa 1989, s. 139-141).

43 Święty Bernard z Clairevaux w Kazaniu na Wieczerzq Pańską. O chrzecie, Sakramencie Oltarza i umyciu nóg, Sancti Bernardi in Coena Domini sermo. De baptismo, sacramento altaris et ablutione pedum, PL 183, 271. 
Co zowiemy figurami.

Luterus, De formula missandi

U Lutera osoby były mało ważné. nié ich przez przyjęcié wiarą ciała Pańskiégo sprawuje miłość uprzéjma chrześcijańsk $a^{44}$. Co tedy widzimy znakiem rzeczy świętéj - chlebem, figurą zwać musimy, jako i inszy przed nami chrześcijanie zwali - lecz co wiérzymy pod osobami, to jest prawdziwé ciało i prawdziwa krew Pana Jezu Chrysta. Niechajże cię tedy nie zgarszają Pisma u Doktorów, także i u Pawła świętégo, kiedy zową zwiérzchnié znaki chlebem, winem, sakramentem, figurą i znakiem, gdy już widzisz, dla któréj przyczyny to czynią, lekce ich téż sobie nie uważaj ani wzgardzaj, gdy widzisz że nie lada czego, ale prawdziwégo i w nich będącégo ciała Pańskiégo własnémi znakami i figurami są, istotę prawdziwą rzeczy niewidomych i obietnic zbawiennych w sobie odnosząc, bo są kształtem widomym łaski Bożej niewidoméj $j^{45}$. [...]

Cóż tedy ci rzeką, którzy o osoby tak wiele sie wadzą? Zwiérzchnié znaki tak wiele poważają? Zwierzchnim znakom tak wiele mocy dają i o nie sie swarząc, jedność chrześcijańską łamią i psują - a prawie błąd Nestoryjuszów przywrócić i wskrzésić chcą, żeby osobno ciało i osobno krew była wiernym dawana? Aza nie wiedzą tego, że i Luter, téj nauki wznawca, nie tak wielką pracą o dwu osobach miał, aby je pod potrzebą zbawienia przyjmować kazał, ale mu o to szło, żeby jedno od posłuszeństwa powszechnégo Kościoła i jego zwiérzchniégo pastérza lud chrześcijański odwrócił i z jedności chrześcijańskiéj rozerwał; co sie jaśnie z tego pisma jego pokazuje, abowiém tak mówi: „Jeśliby jakim przypadkiem papież albo koncylijum - to jest sjem duchowny

44 W postylli: „sprawcą, miłość uprzéjmą chrześcijańską”; poprawiono na podstawie erraty i druku Kazania z 1579 roku.

45 W postylli: „łaski Bożej niewidomym”; popr. red. 
ze wszégo świata zgromadzony - oboję osobę chleba i wina przyjmować rozkazali, my nie chcielibyśmy tego u swych naszladowców, aby dwie osobie przyjmować mieli, i na ostatek powiedamy: na wzgardę papieża i koncylijum chcielibyśmy to, żeby ani jednéj, a na ostatek żadnéj moi nie używali, bo zgoła wszytki takié mojéj Ewanjelijéj naszladowce przeklęté chcemy mieć, którzy by takiégo koncylijum, któré by dwie osobie przywróciło, słuchać mieli”46. Dawał temu Luter przyczynę taką, że Pan Chrystus nic w tym zbawieniu potrzebnégo nie postanowił. Otóż widzisz i Lutra, że tak barzo u siebie osob widomych nie poważał, a zgoła tak je porzucał, że téż i żadnéj na despekt papieżowi i koncylijum przyjmować nie kazał; widzisz téż co powieda, że Chrystus nic w tym potrzebnégo nie postanowił ku zbawieniu. Kiedy by to rzékł i napisał powszechnégo rzymskiégo Kościoła Doktór który, jakie by nań krakanié, jakie wołanié, jakie by łajanie było! Lecz iż Luter, który sie zowie piątym ewanjelistą, wtórym Elijaszem, prorokiem który skały kruszy, to mówił - a to od niego wszytko wdzięcznie przyjmują, słowy krasomownémi to farbują i słowa té jego jako inszé wszeteczné pisma, sprośné malowania tak chwalą, jako Akaronite Beelzebuba, jako Filistynowie Dagona, jako Żydowie Beelfegora $^{47}$, jako pogani bałwany swoje, tak jego naszladówcy przed jego taką sprośną nauką rozumem

Przeciwko onym, którzy Lutra ledwie nie za Boga mają.

46 Tę tezę Marcina Lutra przytaczają dokumenty Soboru Trydenckiego (P6: VIII, 7). Nie jest to dokładny cytat z dzieła Formula missae et communionis pro Ecclesia Wittembergensi, Wittembergae 1523, wyd. Martin Luther Studienausgabe, Bd. 1, Berlin 1979, s. 365-386.

47 Beelzebub - bóstwo much czczone w Ekronie (2 Krl 1,1-5); Dagon - czczony przez Filistynów (Sdz 16,23), Baal-Peor - bóstwo Moabitów, któremu Żydzi złożyli hołd (Lb 25,3). 
Błędy Luterowé o Sakramentcie ciała Pańskiégo.

Ioan. 6, ver. 53. Przywodzi Pismo o dwu osobach. swym i wiarą upadają; a jako oni bałwochwalcami byli, tak ci luterochwalcami zostali.

Lecz nam na tym dosyć, że to pokazaliśmy - nie dla nas wiernych starożytnych chrześcijanów, ale dla tych, którzy Lutra ledwo nie za boga mają - z tegóż samégo Lutra pisma, co o znakach widomych chleba i wina jego była za nauka. Ukazał to przed nami za żywota jeszcze Luterowégo jeden prostégo rzemiosła człowiek, Kasper Quetamer ${ }^{48}$, w mieście Hali, że tenże piąty ewanjelista Luter trzydzieści i sześć błędów i niezgodliwych nauk o tym Sakramentcie w księgach swych napisał, a każdy był sobie opaczny. Otóż macie, jakiému człowiekowi ci zbawienia swego wierzą, którzy nauki jego słuchają. Mnimam, żeśmy już pokazali, jako człowiek chrześcijański ma u siebie poważać osoby, a jako wiarę, i kiedy obaczy - jako z słusznych i prawdziwych dowodów obaczyć może - że u Pana Boga daleko poważniejsza i przewyższająca jest wiara, będzie sie o tym starał pilnie, aby zupełnie Panu Chrystusowi wiarę zachował, a dla osob zwiérzchnich jedności chrześcijańskiéj nie targał.

I Ale podobno rzeczesz: „Dwie osobie od Pana Chrystusa są rozkazané, jakom to wyższéj z Pisma Świętégo pokazał, bo mówi Chrystus Pan: «Jeśli nie będziecie używać ciała mego i pić krwie mojéj etc.»”. Na coć tak odpowiedam:

Świątość krztu i przyjmowania ciała i krwie Pańskiéj jednakim powszechnym rozkazanim są przykazané, abowiém tak o krzcie Pan mówić raczył do Nikodyma,

48 Caspar Querhammer (zm. 1557) - poeta i muzyk, burmistrz Halle (15341556), autor pieśni religijnych i wielu rozpraw wymierzonych w doktrynę Lutra, m.in. wykazu 36 sprzeczności w jego nauce o sakramencie Eucharystii, Tabula contradictionum Lutheri XXXVI super uno articulo de communione (1535). 
jako mówił o ciele i o krwi swéj do tłuszczéj; tam mówił: „Potrzeba, żebyście sie odradzali $\mathrm{z}$ nowu, a jeśli sie kto nie odrodzi z wody a z Ducha Świętégo, nie może wniść do królestwa niebieskiégo", tu o Sakramencie ciała swego i krwie tak mówi: „Jeśli nie będziecie pożywać ciała i krwie mojéj, nie będziecie mieć żywota w was". Jednakié to tedy i powszechné rozkazania. Pytam ja tedy tego osobnika, który to z potrzeby chce mieć, co tu Pan w tych dwu sakramentciéch rozkazać raczył: kędy sie ci męczęnicy podzieli, którzy prędzéj do męczęnictwa przychodzili dla wiary Pana Chrystusa aniż do krztu? Bo wnet skoro wyznanié wiary Pana Chrystusowéj czynili, tedy albo ogniem, albo mieczem zabijani byli, zwiérzchniégo sakramentu krztu na się nie przyjąwszy - już tedy potępieni są, że krztu nie przyjęli, iż i powszechnégo rozkazania Chrysta Pana o krzcie rozkazanégo nie ziścili? Żaden tego chrześcijański człowiek o nich wyznać nie może, bo to musi wyznać, że roźlanie krwie ich dla wiary Pańskiéj, męczęnictwo ich, ogień, który je spalił, im za krzest był, a jeśliż by z potrzeby zbawienia bez wody żaden zbawión być nie mógł, tedy by i ci Pańscy męczęnicy potępieni być musieli. Musisz tedy zeznać, że woda, acz jest potrzebna do krztu, ale nie tak gwałtownie, żeby potępiała, gdy do niéj który wierny przyść - albo dla ukrócenia czasu z koroną męczęniczą, albo dla niedostatku elementu nie może. Przeto mądrzy Doktorowie w starożytnym Krzest trojaki. Kościele trojaki krzest być uczyli ${ }^{49}$ : wodą, płomieniem

Ioan. 3 , ver. 5 . Wykład miejsca.

Ioan. 6, ver. 53.

Nisi manducaveritis carnem etc.

49 O chrzcie krwi pisał m.in. św. Cyprian (Listy...): „Czyż moc chrztu może być większa i potężniejsza, niż wyznanie, aniżeli męka, gdy ktoś wobec ludzi wyznaje Chrystusa lub swą krwią zostaje ochrzczony?” (s. 270); „Jeśli zeszli (nawróceni heretycy) $\mathrm{z}$ tego świata, to zaliczeni są do liczby tych, którzy byli u nas katechumenami, lecz umarli, zanim zostali ochrzczeni” (s. 293). 
Porównawa

sprawę

krztu do przyjmowania ciała

Pańskiégo. ogniowym i roźlaną krwią. Bo gdy widzieli męczęniki Bożé bez krztu w ogień miotané, mieczem ścinané, tedy on ogień i onę kréw roźlaną za krzest im być poczytali i uczyli. Com o krzcie pokazował i o jego powszechnym rozkazaniu, także téż o przyjmowaniu ciała i krwie Pańskiéj powiedam: jeśli każdy chrześcijański człowiek powinien używać ciała i krwie Pańskiéj i przez tego używania zbawion być według tego Pisma i rozkazania Pańskiégo nie może - dziatki małé i dobrze podrosłé niemowiątka małé u piérsi matek swych będącé - cić są wszyscy wiernymi Pana Chrystusowymi, bo sie przez krzest zstały dziedzicmi królestwa Bożégo, członkami Chrystusowymi, bo z nim obumarły na krzcie, zstali sie wybranym naczynim Ducha Świętégo - nie przyjmują pod widomémi osobami ciała i krwie Pańskiéj - i mająż być przeto potępieni, gdy tak schodzą z tego świata? Kto tak bezpiecznie, bezbożnie wierzyć i uczyć będzie? Ludzie na morzu, po ziemi, w walkach, wierni będąc Panu Chrystusowi, weń uprzéjmie wierząc, dla jego wiary gardła dając, umiérają nagle - i jużże będą potępieni, że ciała i krwie Pańskiéj nie przyjęli? Męczęnicy Pańscy jako przeze krztu, tak przez przyjmowania Sakramentu świętégo $\mathrm{z}$ świata schodzili w szczéréj, prawdziwéj wierze Chrysta Pana - już tedy wiecznégo żywota mieć nie będą, ale potępieni być mają nauką tych osobników, którzy o osobach tak ściśle i gwałtownie rozumieją i té słowa Pańskié tak zwięźliwie, nagle i potrzebnie wykładają? Otóż możesz obaczyć, chrześcijański człowiecze, żeć prawdziwie chrześcijańscy Doktorowie to miejsce Jana świętégo wykładali, że więcéj do duchownégo używania ciała i krwie Pańskiéj té słowa przynależą, aniż do onégo używania, któré jest pod osobami chleba i wina, i przeto tak Augustyn święty mówi: „I czemu 
gotujesz brzuch i zęby? Uwiérz, a jużeś pożywał" ${ }^{50}$. Cóż masz uwierzyć? Uwiérz, że Pan Chrystus ciałem swym na śmierć wydanym i krwią swą dla grzéchów twych wylaną ciebie i wszystek naród ludzki zbawił, wiecznyć żywot dał, dziedzicem królestwa niebieskiégo cię uczynił, ciało swé i kréw prawdziwie i istotnie pod widomémi osobami dla żywota twego wiecznégo tobie i narodowi ludzkiému zostawił - tak gdy uwierzysz, choć usty nie pożywasz, wiarą pożywasz prawdziwégo ciała i krwie Pana Chrystusowéj, bo dobrodziejstwa ciałem i krwią Pana Chrystusa tobie uczynioné do pożytku zbawienia twego obracasz.

I Lecz zasię mówić będziesz: „Już sie tym nie dziwuję ani o nich źle wierzę, którzy albo dla niedostatku lat, albo dla nagkéj przygody, albo dla prędkiégo męczęnictwa przystępować do ciała i krwie Pana Chrystusowéj nie mogli - ale insza mnie, który mam już po temu czas i wolność do naświętszégo Sakramentu przystępować, czemuż go brać nie mam, jako Chrystus postanowił na wieczerzéj - to jest pod osobą chleba i wina - czemu go słuchać nie mam, który tak o kielichu do wszystkich wiernych mówić raczy: «Pijcie z niego wszyscy», czemu tak czynić nie mam, jako wy księża, którzy dwie osobie bierzecie, a nam rozkazawszy pod jedną przyjmować, zakazaliście drugiéj? Czymże jesteście lepszy niż my? Czemuż rozkazania Pańskiégo nie wypełniacie, który kazał wszytkim dawać?".

Na każdé tedy tu pytanié odpowiédź prawdziwą bez żadnéj sofistyjéj tak powiedamy. Powieda przeciwnik jedności chrześcijańskiéj, że Pan Chrystus postanowił na wieczerzéj ostatecznéj swéj pod osobą chleba i wina, czego mu żaden katolik nie bróni i to z nim wyznawa,

Matt. 26, ver. 27. Wykład onych słów Bibite ex hoc omnes.

50 Święty Augustyn, In Joannis Evangelium tractatus CXXIV, PL 35, 1601. 
Dwakroć Chrystus Pan Sakrament ciała swego rozdawał.

Aug[ustinus], lib. 3

De consensu Evangelistarum; Chryso[stomus], hom. 17 super Matth.;

Teophylactus

Lucae 24, ver. 30

Ibidem, ver. 31 iż ono postanowienié na pamiątkę męki swéj, żeby nie była od ludzi zapamiętana, tak sie zstało. Lecz jeśli to już postanowienié Pana Chrystusa odmienić sie nie miało, czemu sam Pan Chrystus to odmienić raczył? Bo dwakroć Pan Chrystus Sakrament ciała swego rozdawać raczył: raz na wieczerzéj pod dwiema osoboma już prawie przed męką swą, drugi raz po zmartwychwstaniu swym tegóż dnia, kiedy zmartwychwstał, dwiema zwolęnikom w miasteczku Emaus pod jedną osobą chleba Sakrament ciała swego dawać raczył, jako świadczą o tym Doktorowie Kościoła chrześcijańskiégo. Aby téż i Doktorowie święci tego nas nie nauczyli, że tam pod osobą chleba prawdziwy Sakrament ciała Pańskiégo oni zwolęnicy przyjmowali ${ }^{51}$, tedy sama historyja Ewanjelijéj tego uczy, bo gdy powiada, jakim sposobem Pan Chrystus wziął chléb - to jest że go błogosławił, łamał i podawał im - tedy własny wizerunk sprawy wieczerzéj Pańskiéj w tym pokazuje. Nadto pożytek chleba onégo od Pana podanégo świadczy, że oni nie prosty chléb od Pana brali, bo przez przyjęcie chleba onégo łuska niedowiarstwa $z$ oczu ich była zjęta, tak że go poznali być prawdziwym Mistrzem swoim, który w piątek przeszły ciérpiał, umarł i był pochowan, i o którym byli barzo zwątpili - czy-li mógł prosty uczynić chléb grzéch niedowiarstwa odjąć i poznanié Pańskié niedowiarkom przynieść? Żaden tego twiérdzić nie może,

51 Święty Augustyn w traktacie O zgodności Ewangelistów przywołuje jedynie cytat dotyczący wieczerzy w Emaus, nie interpretuje jej jednak jako Eucharystii (De consensu Evangelistarum libri quattuor, III 25); Teofilaktus - Teofilakt (przełom XI i XII w.), święty prawosławny, arcybiskup Ochrydy, autor licznych komentarzy do ksiąg biblijnych. Współcześnie Kościół nie stwierdza jednoznacznie, czy uczta w Emaus była Eucharystią czy nie, użyty przy jej opisie czasownik „dawał” pojawia się zarówno przy ostatniej wieczerzy, jak i przy rozmnożeniu chleba i nakarmieniu tłumów. 
aby prosty chléb takié w sobie dary żywota wiecznégo odnosić miał; próżno tedy temu sie sprzeciwić, co święci Doktorowie Duchem Świętym napełnieni nam w piśmie swym zostawili, iż pod osobą chleba ciało swé własné w on czas Pan Chrystus dawać raczył, czego aby jaśniejszy dowód każdému był, z tegoż Pisma Świętégo pokazuję, że na kształt Pana Chrystusów apostołowie i wierni Pańscy, których sie było jednégo dnia świątecznégo na wiarę Pana Chrystusowę nawróciło trzy tysiące, ci wszyscy spółecznie w jednym domu będąc, z apostoły trojakiéj sprawy chrześcijańskiéj używali, o czym tak historyja powiada: „Okrzcili sie i trwali w nauce apostoskiéj, w modlitwach i w przyjmowaniu łamanégo chleba”. Po krzcie trwając w apostolskiéj nauce i modlitwach, przyjmowali w łamanym chlebie prawdziwé ciało Pańskié, bo o prostym chlebie tu ewanjelista Łukasz święty nie pisze, abowiém próżne by słowa pisał, boć każdy żywy chléb je, nie trzeba tego nikomu tak pilnie powiadać. Ale kiedy przekłada ich nabożeństwo, ich sposób życia pobożny i wedle nauki apostolskiéj, tedy téż tego była potrzeba, aby nie przepomniał tego pokazać, że w Sakramentcie, w używaniu chleba własnéj bytności ciała Pańskiégo brać nie przepominali, ale go w widoméj osobie chleba używali. A iż Pan Chrystus i jego święci apostołowie pod jedną osobą chleba Sakrament ten rozdawali, przeto téż i uczeń apostolski, żadnéj w tym wątpliwości nie mając, na kształt mistrzów swoich do takiegóż pożywania ciała Pańskiégo napominał, a ten był Ignacyjus, zwolęnik Jana świętégo $^{52}$ : „Bracia, bądźcie posłuszni biskupa waszégo i kapłanom, którzy są starszymi waszymi, prościuchnym zmysłem, przewrótność na strónę odłożywszy, łamcie 
Ukazuje dlaczego i apostołowie pod jedną osobą dawali. Nazarejczykowie wina nie pijali. Num. 6 , ver. 3 ; Iud. 13 , ver. 4 ; Ierem. 35 , ver. 6 ; Acto. 18 , ver. 18 et cap. 21 , ver. 23 chléb (i pożywajcie go), boć on jest lékarstwo nieśmiertelności, lékarstwo nie umrzenia, ale wiecznégo życia"53, o kielichu tam namniejszégo słowa nie mówi. Otóż baczysz ucznia apostolskiégo, jakiégo sposobu używania ciała Pańskiégo uczy. Obaczże tedy, iż ci ono nie była taka ustawa na wieczerzéj, która by sie była odmienić miała, bo widzisz, że i sam Pan Chrystus odmienić ją raczył, i apostołowie inaczéj nią szafowali, i uczniowie apostolscy inaczéj o niéj uczyli.

g Lecz dziwować sie żaden temu nie ma, dla czego apostołowie wiernym nowo nawróconym do wiary Pana Chrystusowéj dawali pod jedną osobą ciało i kréw Pana Chrystusa, bo to czynili dla pewnéj i słusznéj przyczyny, abowiém którzy z narodu żydowskiégo nawracali sie na wiarę, byli z onych rozmaitych i z rozlicznych ludzi, którzy sie ślubami rozmaitémi Panu Bogu obwięzowali, miedzy którymi byli nazarei ${ }^{54}$, którzy ślubem Panu Bogu uczynionym przysięgali wina nigdy nie pić. Gdyż tedy nazarejczykom wina pić sie nie godziło, aby nie wpadli w krzywoprzysięstwo, apostołowie pod jedną osobą chleba Sakrament ciała i krwie Pańskiéj im dawali, bo gdzie by im byli nowo nawróconym pod osobą wina dawać chcieli, bez wzgorszenia ich to by było być nie mogło; gdy-ż jednak z Dziejów Apostolskich wiemy to, że śluby nazarejczyków dwadzieścia lat po Pana Chrystusowym wstąpieniu do nieba w Kościele apostolskim trwały, któré apostołowie święci tak długo w Kościele chrześcijańskim ciérpieli

53 Idem, List do Efezjan 20, 2.

54 Nazireat - ślub poświęcenia się Panu, zwykle trwał od jednego do trzech miesięcy, jego zewnętrznym przejawem było niedotykanie niczego martwego, powstrzymywanie się od wszystkiego, co wytwarza się z soku winorośli, oraz nieścinanie włosów (Lb 6,121); ślub nazireatu złożył m.in. Samson (Sdz 13,4), również św. Paweł i niektórzy nawróceni składali takie śluby ( $\mathrm{Dz} 18,18 ; 21,23)$. 
dla tego, aby przez prędkié odmienienié ślubów Panu Bogu przez nie obiecanych obrażenia albo wzgorszenia w Kościele powszechnym Chrystusowym nie uczynili.

Toć była przyczyna, dla czego pod jedną osobą Kościół apostolski dawał wiernym Pana Chrystusowym Sakrament ciała i krwie Pana Chrystusa.

A iż tak pod jedną, jako i pod dwiema jednako było przyjmować ten Sakrament za apostołów, tedy tym, którzy sie z pogaństwa nawracali, pod obiema osoboma dawali, dle téj przyczyny, że pogani w błędach swoich pogańskich żywiąc, bogom swoim ofiary w piciu i w jedzeniu czynili, jako o tym i Pismo Święté świadczy. Apostołowie tedy w obojéj osobie chleba i wina dawali im Sakrament ciała i krwie Pańskiéj. To czynili, aby w onéj mdłéj wierze swojéj pogani nie rozumieli, że mniéj z wieczerzéj Pana Chrystusowéj brać i używać mieli aniż z ofiar czartowskich i bałwochwalskich. Otóż baczyć możesz sprawy apostolskié około dawania jednéj i obojéj osoby Sakramentu ciała Pańskiégo, a to bacząc rozumiéć masz, jako apostołowie w piérworodnym Kościele więcéj przestrzégali miłości chrześcijańskiéj i aby żadné wzgorszenié w Kościele Chrystusowym nie było, aniż jednéj albo obudwu osób rozdawania.

g Byłoć to i w starożytnym Kościele, że oboję osobę wielkim rozkazanim kościelnym każdy chrześcijański człowiek przyjmował ${ }^{55}$, bo kiedy Manicheusz heretyk

55 oboje osobę... każdy chrześcijański człowiek przyjmował - św. Augustyn opisywał odrzucenie mięsa przez manichejczyków w dziele Przeciw Faustusowi (XXX, 5; PL 42, 494): „Twierdzicie, że mięso zdziałał diabeł jako smaczniejszy kąsek złej materii i ze względu na to, odrzucacie je jako coś bardziej nieczystego i okropniejszego", św. Augustyn, Przeciw Faustusowi. Księgi XXII-XXXIII. Przeciw Sekundynowi, tłum. J. Sulowski, wstęp i oprac. W. Myszor, tłum. przejrzeli i popr. J. Gliściński et al., Warszawa 1991, s. 121; o odrzucaniu mięsa i wina pisał w Obyczajach Kościoła katolickiego i obyczajach manichejczyków: „Tak więc powstrzymują się nie 
Aug[ustinus], lib. 30

Contra Faustum,

cap. 5 et Libro

de mor[ibus]

Manichae[orum],

cap. 13

Leo Papa Primus, serm[o] 4 de quadr[agesima]; item Leo, Epi[stula] 10 ad plebem Constant [inopolitanae urbis].

De conse[cratione], dist. 2, cap. Comperimus... wzgardzał stworzenié Bożé i powiadał, że każdé stworzenié, któré człowieka przywodzi do upadku grzéchu, złé jest i od złégo początku stworzoné, a iż wino tak hydził i złym czynił, tedy je z używania Sakramentu wymiatał. Co bacząc, powszechnégo Kościoła pastérz zwiérzchni z inszymi wszémi pastérzmi postanowili ${ }^{56}$, aby każdy człowiek chrześcijański był powinien na każdy Dzień Wielkonocny pod dwiema osoboma przyjmować ciało i kréw Pana Jezu Chrysta, iżeby przez to używanié obojéj osoby i błąd Manicheuszów sie wykorzenił, i uczniowie Manicheuszowi miedzy katoliki pomiészani byli od pastérzów Kościoła powszechnégo uznani i z pospolitowania Kościoła powszechnégo odłączeni, i dla téj przyczyny ona ustawa była od Gelazyjusa postanowióna, która tak jest napisana: „Doszliśmy tego pewnie, że są niéktórzy miedzy chrześcijany, którzy przyjąwszy tylko ciało Pańskié pod osobą chleba,

tylko od mięsa i wina [...]", przeciwstawia im wolność w tej materii, którą wiernym pozostawia Kościól: „Ci zatem, którzy mogą, tych jednak jest niewielu, powstrzymują się od jedzenia mięsa i picia wina $\mathrm{z}$ dwóch powodów: albo ze względu na ułomność braci, albo ze względu na własną wolność [woli]", św. Augustyn, Pisma monastyczne, przeł. P. Nehring, M. Starowieyski, R. Szaszka, wprow. G. Lawless, wstęp i oprac. P. Nehring, Kraków 2002, s. 185.

56 Komunia wielkanocna została nakazana przez Sobór Laterański IV, jednak w konstytucjach nie ma mowy, pod jakimi postaciami: „Wszyscy wierni obojga płci, osiągnąwszy pełnoletniość, powinni osobiście przynajmniej raz w roku wiernie wyznać swoje grzechy [...] przyjmując z uszanowaniem w czasie Paschy sakrament Eucharystii”, Dokumenty soborów powszechnych..., t. 2, s. 259. Leo Papa Primus św. papież Leon I Wielki (ok. 440-461) w mowie 42, Na Wielki Post czwartej, pisząc o wielkim poście, ostrzegał przed obłudą manichejczyków: „W następujący sposób się zachowują: od czasu do czasu niegodnymi usty przyjmują Ciało Pańskie, natomiast zupełnie uchylają się od picia Krwi naszego odkupienia", św. Leon Wielki, Mowy, przeł., wstęp i oprac. K. Tomczak, Poznań-Warszawa-Lublin 1958, s. 189. Podobnie o prawdziwej obecności ciała i krwi Chrystusa w Eucharystii pisał w Liście do kleru i mieszkańców Konstantynopola, Epistola LIX ad clerum et plebem Constantinopolitanae urbis, PL 54, 368. 
kielicha krwie naświętszéj Chrystusowéj nie przyjmują. Otóż albo niechaj zupełné sakramenta biorą, albo od zupełnych sakramentów niech sie wstrzymawają, bo rozdzielnie téjże i jednéj tajemnice bez wielkiégo świętokradztwa być nie może" ${ }^{57}$. Ta ustawa tego kanonu niskąd inąd nie poszła na on czas, jedno aby błąd Manicheuszów był wykorzenion, przed którym błędem w Kościele chrześcijańskim powszechnym począwszy od apostołów tak pod jedną, jako i pod dwiema osoboma ciało Pańskié i krew od wiernych było przyjmowané i jako który z wiernych chciał rozdawané.

Lecz iż szatan zawżdy nie śpi, po błędzie Manicheuszowym z Kościoła świętégo wykorzenionym nie przestał pobudzać, jedność chrześcijańską targając, i inszych heretyków, którzy około tegóż Sakramentu rozmaité opinije albo mnimania w ludziach czynili; więc jako zawżdy na nowé choroby nowé lékarstwa lékarze wynajdować muszą, tak Kościół święty powszechny chrześcijański na nowé błędy nowych lékarstw szukać zawżdy musiał i musi, bo po zgładzonym błędzie Manicheuszowym ludzie chrześcijańscy zasię na kształt czasów apostolskich i nauki ich jedni pod jedną, a drudzy pod dwiema osobami przyjmowali, nic sie $\mathrm{z}$ tego nie gorsząc, i owszem więcéj pod jedną aniż pod dwiema przyjmując. I przeto u nas w Polszcze daléj niżli od sześci set lat wiarę chrześcijańską przyjąwszy, nigdy inakszy sposób używania ciała i krwie Pańskiéj nie był, jedno pod jedną osobą, i odmiana tego zwyczaju nigdy u nas nie była, dopiéro od lat kilu dziesiąt - za wstępem do nas nauki Luterowéj - wznawiać tę naukę uczniowie Luterowi poczęli i tym przysmakiem w serca ludzkié sie

57 Gelazy I, papież w 1. 492-496; Gelasius Maiorico et Ioanni Episcopis, PL 59, 141.

Polacy zawżdy pod jedną osobą przyjmowali. 
wkradać wszczęły, hydząc starodawną wiarę przodków naszych im od apostolskich namiestników podaną.

Widząc tedy on wąż stary i chytry, że z prostości chrześcijańskiéj ludzie chrześcijańscy pod dwiema osobami i pod jedną wedle woléj swojéj przyjmowali ciało i kréw Pańską, jął siać niezgodę miedzy wiernymi, iż jęli wzgardzać jeden drugiégo, lepszymi sie jedni nad drugié czyniąc, o osoby sie waśniąc i wadząc, błąd nestoryjański ${ }^{58}$ i inszé błędy wzruszając, własność ciała Pańskiégo i krwie z widomych osób wymiatając, z prostoty Kościoła świętégo chrześcijańskiégo przez heretyki sie natrząsając. Do takich je rozruchów i niesnask przywiódł przez hussyty ${ }^{59}$ - Jana Hussa dyscypuły - powiadając, że przyjmowanié pod dwiema osoboma jest i być ma $z$ potrzeby zbawiennéj, a inaczéj człowiek zbawión być nie może.

Co widząc Kościoła powszechnégo zwiérzchnié członki, pastérze i szafarze słowa Bożégo, że potrzeba była w téj i w takiéj nauce fałszywéj chytrość szatańską zniszczyć i utrzeć, aby jego śmiałość była pokazana, fałszywa nauka odkryta, dla pewnych i potrzebnych przyczyn jako piérwéj dwoję osobę Sakramentu wszytkim pod posłuszeństwem chrześcijańskim brać rozkazali byli, błąd Manicheuszów gładząc, tak zasię dla wielkich i potrzebnych przyczyn jednę osobę Sakramentu zatrzymali na Koncylijum Konstantyńskim i Bazyli-

58 Por. wyżej.

59 Jan Hus (1370-1415) - czeski teolog, uczony, reformator Kościoła, uznany za heretyka i spalony na stosie, po jego śmierci naśladowcy starali się wcielać w życie zasady zawarte $\mathrm{w}$ tzw. czterech artykułach praskich; jeden $\mathrm{z}$ nich mówił o przywróceniu Komunii pod dwiema postaciami; rozruchy i niesnaski - po spaleniu Husa doszło do powstania przeciwko Zygmuntowi Luksemburskiemu, oskarżonemu o przyczynienie się do tej śmierci, powstanie przerodziło się w wojny religijne trwające do 1436 roku. 
jeńskim ${ }^{60}$ do czasu pewnégo, któré przyczyny, aby były każdému wiadomé, każdą z osobna tu jaśnie powiémy.

g Naprzód dla tego, com piérwéj ukazał, aby błąd nestoryjański miedzy wiernémi Pana Chrystusowémi miejsca nié miał i osobnym przyjęcim ciała pod osobą chleba, osobnym zasię przyjęciém krwie pod osobą wina, ciała i krwie Pana Chrystusowéj różnie nie rozłączał, gdyż pod obiema osobami zupełny Chrystus jest i rad bym wiedział, jako by mi ci odpowiedzieli, którzy tak wiele sie o osoby obie starają, bo jeśli pod osobą chleba prawdziwé ciało żywé i nieśmiertelné przyjmują - jakóż tak wiarą swą przyjmować mają - czemu sie o krwi pytają, która być zawsze musi w żywym ciele? A jeśli tak rozumieją, że bez drugiéj osoby niezupełné ciało Chrysta Pana jest beze krwie, tedyć ciało martwé i kréw martwą przyjmują. A gdziéż sie oné słowa Pańskié podzieją: „Jam jest żywy chléb, którym z nieba zstąpił"? A jeśliż Chrystus Pan pod osobą chleba jest żywy, tedyć pod tąż osobą chleba ma kréw żywą - czy martwé ciało Pana Chrystusowé i martwa krew ciebie ożywi? Żadnym obyczajem i żadnym sposobem to być nie może. Apostołowie, acz śmiertelné ciało Pańskié brali, także i krew, nie z strony onéj śmiertelno-

60 Na soborze w Konstancji (1414-1418) potępiono udzielanie świeckim Komunii pod dwiema postaciami: „Podobnie jak zwyczaj ten słusznie wprowadzono dla uniknięcia pewnych niebezpieczeństw i zgorszeń, [...] choć w Kościele pierwotnym wierni przyjmowali ten Sakrament pod dwiema postaciami, to jednak później pod dwiema postaciami przyjmował go tylko konsekrujący, a wierni jedynie pod postacią chleba. Z całą pewnością należy jednak wierzyć i nie wątpić, że ciało i krew Chrystusa w całości zawierają się zarówno pod postacią chleba, jak i wina" (Sesja 13, w: Dokumenty soborów powszechnych..., t. 3, s. 109). Ta sesja nakłada również karę ekskomuniki na kapłanów udzielającym wiernym Komunii pod dwiema postaciami. Na soborze w Bazylei potwierdzono naukę ogłoszoną w Konstancji w kwestii udzielania Komunii. 
ści przyszłéj, która to ciało potkała na krzyżu, pokarm wiecznégo żywota brali, ale względem onéj nieśmier-

Matt. 27, ver. 63

Ioan. 16, ver. 17

Rom. 6, ver. 9

Urbanus Regius in suis Locis communibus telności, o ktoréj im Pan mówić raczył: „Trzeciégo dnia zmartwychwstanę i tak po małym czasie oglądam was". Ta Chrysta Pana nieśmiertelność nieśmiertelné swé ciało apostołom i nam wiernym swym zostawiła, o któréj tak Paweł święty mówi: „Chrystus wstawszy od umarłych już nie umiéra i śmierć mu więcéj nie panuje”. Przeklęty tedy błąd był Nestoryjuszów, który jeszcze Koncylijum Efeskié przed tysiącem lat poznało ${ }^{61}$, i w każdéj osobie zupełnégo i żywégo Pana Chrystusa być uczyło, o czym nie tylko naszégo Kościoła Doktorowie, ale téż i uczeń Luterów ${ }^{62}$ jaśnie świadczy, że tak a nie inaczéj było, dla czego téż i po dziś jedna osoba Sakramentu jest zahamowana, przeto i Grékowie, Ruś i inszy naszladowcy patryjarchatu gréckiégo, aby rozdziału żadnégo w Sakramentcie nie pokazali i Nestoryjańskiégo błędu w rozdzielności osób dla rozdziału ciała i krwie nie naszladowali, gdy ciało Pańskié pospolitemu człowiekowi rozdawają, tedy naprzód przez dyjakona tak ludzie uczą: „Przyjmujcie ciało nieśmiertelné i krew nieśmier-

${ }^{61}$ Sobór Efeski (431) przedstawił poglądy na temat natury Chrystusa; Trzeci list Cyryla do Nestoriusza: „kiedy głosimy śmierć według ciała Jednorodzonego Syna Bożego [...], uświęcamy się, stając się uczestnikami w świętym ciele i drogocennej krwi Chrystusa. [...] mamy uważać, że jest ono prawdziwie własnym ciałem Tego, który dla nas stał się i został nazwany Synem Człowieczym", Dokumenty soborów powszechnych. Tekst grecki, łaciński i polski, t. 1: Nicea I, Konstantynopol I, Efez, Chalcedon, Konstantynopol II, Konstantynopol III, Nicea II (325-787), układ i oprac. A. Baron, H. Pietras, [przeł. A. Baron et al.], Kraków 2001, s. 143.

${ }^{62}$ Urban Rieger (Rhegius, 1489-1541), niemiecki teolog i działacz reformacyjny, autor rozprawy Loci theologici e patribus et scholasticis neotericisque (Frankfurt 1545): Graeci, Rutheni sic communicarunt, similiter Ioannes Wicklef, Ioannes Hus, Rockenzan, „W ten sposób przyjmują komunię Grecy, Rusini, podobnie Jan Wiklef, Jan Hus, Rockenzan", Opera Urbani Regii latine edita, Nürnberg: Johann vom Berg i Ulrich Neuber, 1562, k. CCCXVIIIv, przekład własny. 
telną Pana Jezu Chrysta; a choć z ciała wytoczona była, przedsię nieśmiertelna jest"63; i póki jedno przyjmują ludzie, póty dyjakon to napominanie śpiéwając czyni: „Przyjmujcie etc.” K temu nie osobno osoby wina i chleba, ale razem w kielichu zmiészawszy ciało i krew w osobach chleba i wina łyżką pop dawa wszytkim, którzy na ziemię upadając przyjmują i do Sakramentu z uczciwością wielką przystępują. A chorym zasię pod osobą chleba $\mathrm{w}$ winie poświęconym namoczywszy go i ususzywszy Sakrament dawają, bo taki Sakrament dla chorych w cérkwiach ustawicznie chowają. A baczysz, jako tego błędu Nestoryjuszowégo nie tylko w Rzymskim Kościele, ale téż i u Gréków pilnie sie przestrzégają i przeto osób rozdzielnie używać nie dają, i ciało Pana Chrysta, także i krew jego, żywé i nieśmiertelné być wyznawają, pod jedną osobą chorym dawają, boć już tam wszytka wilgotność wina wyschnie i w materyją chleba sie obróci.

Ku krzywdzie tedy tu powiadają szarpacze jedności Kościoła Chrysta Pana onemu, który jest przednim pastérzem Kościoła chrześcijańskiégo, aby to wymysły jego albo ustawa Koncylijum Ko[n]stantyńskiégo była, gdy ten zwyczaj przyjmowania pod osobą chleba ciała i krwie Pańskiéj trwał zawżdy w Kościele świętym. Przeto święty Agapetus niemégo i chromégo człowie-

Lib. 3 Dialo[gi], De consecr[atione] 2 ka przez danie ciała prawdziwégo Pańskiégo pod jed-

63 Nie udało się dotrzeć do źródła cytatu. Według liturgii św. Jana Złotoustego diakon przed udzieleniem Komunii wiernemu wypowiada następujące słowa: „Sługa Boży N. przyjmuje najdroższe i święte Ciało i Krew Pana i Boga i Zbawiciela naszego Jezusa Chrystusa na odpuszczenie grzechów swoich i na życie wieczne, amen”. Sami wierni przed przyjęciem Komunii wypowiadali modlitwę: „Wierzę także, że to jest nieskalane Ciało Twoje i że to jest drogocenna Krew twoja” (Boska Liturgia św. Jana Złotoustego, http://www.cyrylimetody.marianie.pl/pliturgia/ pliturgia3d.htm, dostęp: 22.05.2018). 
ną osobą uzdrowił, jako Grzegórz święty świadczy ${ }^{64}$. Koncylijum Remeńskié ${ }^{65}$ pokazuje, iż do chorych pod osobą chleba tylko ciało Pańskié noszoné bywało, i aby tego prości laicy nie śmieli sie ważyć, zakazano. Przeto i Ambroży święty, mowiąc o przystępowaniu do Sakramentu ludzi pospolitych, o jednéj osobie tylko chleba wspomina ${ }^{66}$. Stary to tedy zwyczaj był, iż każdy brał jako chciał, albo pod dwiema, albo pod jedną, który to zwyczaj pod jedną osobą brania umocnion jest przez Koncylijum Konstantyńskié ${ }^{67}$ już dla powyższéj namienionégo błędu, także i dla inszych wiele przyczyn, któré już pokażemy.

64 Agapit I, papież w latach 535-536, święty Kościoła katolickiego i prawosławnego, w drodze do Konstantynopola uzdrowił chromego i niemego człowieka przez udzielenie mu Komunii; historię tę opisuje św. Grzegorz Wielki w Dialogach: „Po niedługim czasie również błogosławiony Agapit biskup świętego Rzymskiego Kościoła, któremu służę z woli Boga, udał się do cesarza Justyniana. Pewnego dnia, jeszcze w drodze do Grecji, przyniesiono mu niemego i chromego, aby go uleczył; ten nie mógł ani słowa wymówić, ani w ogóle podnieść się z ziemi. Gdy go krewni z płaczem przynieśli, pilnie ich wypytywał, czy mają ufność w jego uleczenie. Skoro mu powiedzieli, że mocno ufają, że mocą Boga i powagą Piotra go uleczy, zaraz czcigodny mąż zaczął się modlić i rozpocząwszy Mszę, złożył Ofiarę w obliczu wszechmocnego Boga. Następnie odszedłszy od ołtarza chwycił chromego za rękę i na oczach ludu postawił go na nogi. Gdy Ciało Pańskie do ust mu włożył, jego język, tak długo niemy, został rozwiązany i zaczął mówić”, św. Grzegorz Wielki, O Agapicie świętym papieżu, w: idem, Dialogi, przeł. W. Szołdrski, wstęp J.S. Rojarski, oprac. E. Stanula, Warszawa 1969 [właśc. 1970], s. 101.

65 Synod w Reims obradujący w latach 627-630 przyjął kanon o Wiatyku (viaticum), Komunii udzielnej ludziom chorym, często umierającym.

${ }^{66}$ Święty Ambroży w Kazaniach o sakramentach, które wygłaszał katechumenom, wspomina co prawda w jednym miejscu „Ale ten jest chlebem tylko dopóty, dopóki nie padną słowa sakramentalne. Od konsekracji chleb staje się Ciałem Chrystusa" (św. Ambroży z Mediolanu, O sakramentach, IV 14, w: idem, Wyjaśnienie symbolu. O tajemnicach. O sakramentach, przeł., wstęp i oprac. L. Gładyszewski, Kraków 2004, s. 87), choć mówi również o obu postaciach (ibidem, s. 86-88).

67 Por. wyżej. 
I Druga przyczyna, która przywiodła Kościół powszechny, aby pod jedną osobą dawano każdému okrom tych, co Mszą mają - bo i ci okrom Mszéj pod jedną osobą przyjmują - błąd Berengaryjuszów ${ }^{68}$, który za czasów naszych wzbudził Ulryk Zwinglik ${ }^{69}$, Jan Kalwin i inszy. Ten Berengaryjus uczył i uczą jego naszladownicy po dziś, że własnéj bytności ciała Pańskiégo pod osobami niemasz, ale hasło zbawienia, pamiątka męki i znak tylo ciała Pańskiégo za nas wydanégo jest, i przyjmowanié nie jest tam będącégo i prawdziwégo ciała w nich, ale duchownym obyczajem (jako oni zową) - to jest że gdy znaki zwierzchnie przyjmują, do pożytków dusze swéj dobrodziejstwa męki Chrysta Pana i jego odkupienia przywłaszczają, pamięć obchodząc męki Pańskiéj, ale własnéj bytności ciała Pańskiégo wedle brzmiących słów: „To jest ciało moje, to jest krew moja" nie wierzą ani wyznawają, powiadając, że wstąpił na niebiosa i siedzi na prawicy u Boga, przeto go tu niemasz - i dla tego tedy, żeby zawżdy trwała wiara własnych słów Pańskich, że jest ciało jego prawdziwé pod osobą chleba, i procesyje z ciałem Pańskim pod osobą chleba, i używanié pod jedną osobą jest postanowioné. Abowiém zawżdy té jady błędów szatanskich przeciwnym lekarstwem léczyć sie muszą. Oni

68 Berengariusz (ok. 1000-1088) - archidiakon z Tours, który opowiadał się za symboliczną obecnością Chrystusa w Eucharystii.

69 Ulrich Zwingli (1484-1531) - szwajcarski kaznodzieja i teolog, ksiądz katolicki, zainspirowany nauką Lutra, zaczął krytykować Kościół katolicki i jego nauczanie, w końcu z niego wystąpił, popadł również w konflikt z Lutrem, gdyż zanegował obecność Chrystusa w Eucharystii. Luter nazwał go „marzycielem” i wydał pismo Krótkie wyznanie o świętym sakramencie przeciw marzycielom (Kurzes Bekenntnis vom heiligen Sakrament wieder die alten und neuen Sakramentsschwärmer, Wittenberg 1567); Jan Kalwin (1509-1564) głosił symboliczną jedynie obecność Chrystusa w Eucharystii. 
Vide Conradum Clingium in Summa doctrinae Christianae, titulo 92 powiadają, że widomé osoby znaki tylko ciała Pana Chrystusa są, a starożytny apostolski Kościół nie wstydając sie prostoty Ewanjelijéj świętéj, w procesyjach $\mathrm{z}$ ciałem Pańskim i w dawaniu pod jedną osobą, i pod każdą z osobna śpiéwa, mówi, napomina i uczy onych słów Chrystusowych: „To jest ciało i kréw moja”; a im oni nadaléj przy swym błędzie trwają, tym my więcéj tę prawdę objaśniać mamy, wyznawając pod jedną osobą być prawdziwé, żywé i zupełné ciało Pańskié ze krwią i z bostwem.

g Trzecia przyczyna: byli zasię niektórzy tak domyślni ${ }^{70}$, którzy więcéj łaski Bożéj powiedali być w kielichu aniż w osobie chleba, a mieli po sobie dowód słów Pańskich, bo powiedali, że z kielicha wszytkim rozkazał Pan Chrystus pić, a osoby chleba nie wszytkim kazał używać. Rozumieli tedy, że $\mathrm{z}$ potrzeby przykazania z kielicha pić pożyteczniéj im było ku zbawieniu, aniż pod osobą chleba ciała i krwie Pańskiéj pożywać. Trzeba tedy to było tak zrównać, aby każdy tak w osobie chleba, jako i w osobie wina rownie zupełnégo Chrystusa wierzył i pożywał.

g Czwarta przyczyna, że sie wielka nieuczciwość Sakramentowi ciała Pańskiégo działa przez rozléwanié z kielicha u ludzi mdłych, chorych, barzo starych i w ciżbie, czego jako przestrzégali w piérworodnym Kościele ludzie święci, aby taka nieuczciwość nie była czytaj o tym w naszym Katechizmie ${ }^{71}$.

70 Konrad Klinge (1483-1556) - franciszkański teolog, autor dzieła Summa doctrinae christianae catholice, Köln 1570.

71 W Katechizmie Białobrzeski przywołuje pisma pierwszych ojców Kościoła: św. Ignacego, Justyna Męczennika, Ireneusza i ich świadectwa o przyjmowaniu z wiarą ciała i krwi Chrystusa (Katechizm..., s. 272-275). 
g Piąta przyczyna, dla czego zahamowana jest osoba wina: bo sie najdowali i najdują tacy ludzie, którzy nie tylko żeby wino mieli pić bez obrzydzenia, ale i woniać go nie mogą. Są téż takie krainy, kędy sie wino nie rodzi $^{72}$ i do nich przyniesioné wnet skwaśnieje - jużże tedy tacy ludzie winem sie brzydzący i takié krainy albo ludzie wierni w onych krainach, gdzie wino być nie może, nie mają ciała Pańskiégo prawdziwégo przyjmować, że drugiéj osoby przyjmować nie mogą? Być to nie może. Temu tedy folgując a żeby wzgorszenié nie było i Sakrament ciała Pańskiégo wszędy jednostajnie był przyjmowan, zachowana była i jest jedna osoba. A przeto i Luter, także i uczeń jego Brencyjus ${ }^{73}$, pozwala na to, iż pod jedną osobą jest zupełny Chrystus, abowiém to wiedzieli, że natur ludzi obrzydliwych i krain świata inaczéj nad wolą Bożą postanowić i odmienić nie mogli - baczyli, żeby dla niedostatku wina i dla

Luter[us], tomo 2,

Vitemb[ergae], fol. 30;

Brencius

in Apolo[giam]

Vitemb[ergensis],

2 parte

72 Na północy Europy, szczególnie w Skandynawii, Irlandii, Szkocji, wino było trudno dostępne i drogie.

${ }^{73}$ Marcin Luter w Wyznaniu augsburskim (Confessio fidei exhibita [...], Wittenberg 1530) pisał: „Kościoły nasze uczą o Wieczerzy Pańskiej, że ciało i krew Chrystusa są prawdziwie obecne i rozdzielane spożywającym w Wieczerzy Pańskiej; inaczej nauczających odrzucają" (cyt. za: Wieczerza Pańska w Ksiegach Wyznaniowych Luteranizmu. Mały Katechizm ks. dr Marcina Lutra: Konfesja Augsburskaz 1530 r., p. X, https://www.luteranie.pl/materialy/rozne_pisma/wieczerza_panska_w_ksiegach_ wyznaniowych_luteranizmu,330.html, dostęp: 12.06.2018). Co do przyjmowania Najświętszego Sakramentu pod dwiema postaciami - Luter pisze: „Osobom świeckim udziela się obu postaci sakramentu Wieczerzy Pańskiej, ten bowiem zwyczaj oparty jest na przykazaniu Pana: Pijcie z niego wszyscy" (Wyznanie augsburskie (Konfesja Augsburska) z 1530 roku. 95 tez ks. Marcina Lutra z 1517 roku, [wstęp M. Uglorz, przeł z j. niem. A. Wanuta, przeł. z j. łac. J.W. Jackowski], Bielsko-Biała 1999, s. 46). Johann Brenz (1499-1570) w obronie Wyznania augsburskiego (In apologiam Confessionis... D. Christophori, Ducis Wirtenbergensis etc. prolegomena, Frankfurt 1555), w części drugiej - De autoritatae Scripturae - pisał o tych, którzy proste słowa „Pijcie z niego wszyscy” interpretują jako „niektórzy”. Nie ma tam jednak mowy o zupełnej obecności Chrystusa pod jedną postacią. 
obrzydliwości jego wiele ludzi od Sakramentu wstrzymawać sie musiało i nie pożywać go, przeto wyznali to, radzi nie radzi, że pod jedną osobą chleba jest zupełny i prawdziwy Chrystus - to jest ciało prawdziwé zupełné ze krwią Pana Chrystusowé. Tak prawda i od upornych nieprzyjaciół jednéj osoby musiała być wyznana, tak przez té Kajfaszé ${ }^{74}$ chciał Pan Bóg wiernym swym oznajmić prawdę, aby znali, że w jednéj osobie zupełnégo Chrystusa przyjmują.

g Ostateczna przyczyna, a ze wszytkich najwiętsza, aby pokazał Kościół Boży tak być zupełnie Pana Chrystusa pod jedną, jako i pod dwiema osoboma, bo sie tego nauczył, iż tak zacné upominki łaski Bożéj ten bierze, który jednéj osoby używa, jako i ten, który Pana Chrystusa pod dwiema osobami przyjmuje.

Co aby każdy wiedział, iż tak jest a nie inaczéj, czworaką obietnicą Pańską tego dowodzę:

g Mówi tak u Jana świętégo, sam siebie niebieskim Ioan. 6 , ver. 50 chlebem zowiąc: „Ten jest chléb, który z nieba stąpił, który go będzie używał, nie umrze".

g Wtóra obietnica Pańska tym, którzy prawdziwégo ciała jego pożywają pod osobą chleba, ta jest, którą Żydom opowiedział Pan, mówiąc: „Ojcowie waszy jedli

Ioan. 6 , ver. 49 ; ibidem, ver. 51

Ibidem, ver. 48 ; ibidem, ver. 57; ibidem, ver. 51 mannę na puszczy, a pomarli są; który używa tego chleba, będzie żył na wieki”.

g Trzecia obietnica jest ona, którą Pan mówi: „Jam jest chléb żywota, który mię pożywa, będzie żył dla mnie".

${ }^{74}$ Te Kajfasze - mowa o niegodziwcach, którzy chcąc zaszkodzić jakiejś sprawie, mimowolnie jej pomagają; określenie pochodzi od arcykapłana Kajfasza, który aby przekonać synagogę o konieczności zabicia Chrystusa, wypowiedział słowa: „Lepiej jest dla was, gdy jeden człowiek umrze za lud, niż miałby zginąć cały naród" (J 11,50). 
g Czwarta obietnica Pana naszégo jest ona, kędy mówi: „Chléb, który ja wam dam, ciało moje jest, któré ja wydam za żywot wszytkiégo świata".

Patrzże, chrześcijański człowiecze: przyjmujesz pod jedną osobą chleba prawdziwé ciało Pańskié, co tobie za to Pan obiecał? Śmiercią nie umrzesz - to jest wieczną na duszy twéj - w Chrystusie żyw jesteś i dla Pana Chrysta mieć żywot będziesz, ciała prawdziwégo Chrystusowégo używasz, któré jest dané nie tylko za żywot twój, ale za żywot wszytkiégo świata.

I Na ostatek żywiesz wiecznym żywotem na wieki. Czegóż więcéj chcesz? Czegóż żądasz? Czego pragniesz, gdy-ż tak wielkié obietnice przy używaniu ciała jego pod jedną osobą na sobie odnosisz i pewnym ich być masz?

Takieć obietnice Kościół święty bacząc a przyczyny do tego wielkié mając (któré sie już powyższéj pokazały) hamował osobę jednę, wszakże nigdy Kościół Boży o tym nie wiedział ani to kiedy w nim było, żeby tym odjęcim jednéj osoby Sakrament ciała Pańskiégo rozdzielić i tak go umniejszyć miał, i od ciała kréw odłączyć, bo tak wierzył zawżdy i uczył, że tak pod osobą chleba, jako i pod osobą wina zupełny i wszytek jest Chrystus, lecz o tym powyższéj dosyć sie napisało. Ale rzeczesz: „Czemuż Pan rzékł "pijcie z kielicha wszyscy»? Toć nikogo nie odłączył, ale wszytkim wiernym rozkazał, aby pili”. Zeznawam i pozwalam tego, że wszytkim kazał na onéj wieczerzy pić - to jest wszystkim dwanaście apostołom, którzy z nim siedzieli i do których to mówił, bo jeśliby do wszytkich wiernych ta mowa Pańska miała sie rozumieć - jako osobnicy mieć chcą - i do wszytkich miało być rzeczono, tedyć nie jedno dwanaście swych wiernych miał Chrystus na on czas, abowiém miał siedmdziesiąt uczniów swoich, miał Nikodéma i Jozefa potajemné zwolęniki - miał nad apostoły i nad té po- 
Lucae 23, ver. 27; Ioan. 19 , ver. 25

Marci. 14, ver. 23 mienioné wszystki naświętszą i wiarą przedniejszą Matkę swą miłą - przeczysté naczynié Ducha Świętégo miał téż i oné święté panié, któré go majętnościami swémi podpomagały, za nim żałobliwie płacząc na górę Kalwaryją szły, przy ukrzyżowaniu jego były, serdecznie go żałując.

g Jeśliby tedy słowa „pijcie wszyscy” na wszytki onégo czasu wierné przynależały, czemuż nie była przypuszczona Panna, zwolęnicy, panie święté, aby wszyscy z apostoły z kielicha pili? Nie do wszytkich tedy wiernych Pana Chrystusowych przynależały té słowa, ale do onych wszytkich, którzy z Panem Chrystusem siedzieli, co Marek święty jaśnie pokazuje, gdy mówi: „Dał kielich po uczynieniu dzięki im - to jest apostołom - i pili z niego wszyscy”. Panna naświętsza Maryja, zwolęnicy i inszy wierni w Dzień Świąteczny pod osobą chleba ciała Pana Chrystusowégo wiarą przyjmowała i przyjmowali, tego nie czytamy, aby jéj i im mowióno: „Pijcie z kielicha wszyscy".

Otóż baczyć możesz, jako masz rozumieć z Kościołem chrześcijańskim té słowa „pijcie z tego wszyscy”.

Ale jeszcze kto mówić będzie: „Czemuż wy księża przyjmujecie pode dwiema osoboma? Czyście wy lepszy niż my, którym zakazujecie dawać? I nie dawacie tak nam, jako sami przyjmujecie?". Na to tak odpowiedam: w stanie kapłańskim dwojakié jest przyjmowanié ciała Pańskiégo: jedno jest we Mszéj pod dwiema osoboma, drugie jest okrom Mszéj, a tam kapłan każdy pod jedną osobą przyjmuje, jako i drudzy chrześcijanie, którzy nie są kapłanmi. Iż na Mszéj pod dwiema osoboma przyjmuje, nie czyni tego tym sposobem, aby wierzyć nie miał, że pod każdą osobą zupełny jest Chrystus, ale to czyni dla pewnéj onéj tajemnice, którą sprawuje we Mszéj. 
Abowiém Msza nic inszégo nie jest, jedno własny wizerunk i konterfet męki Pana a zbawiciela Jezu Chrysta, iż jako on krwawym obyczajem sam siebie ofiarował przez mękę swą Bogu Ojcu za nas, za przyczyną okrutnych rąk żydowskich, tak szafarze tajemnic Pańskich, kapłani, niekrwawym obyczajem, pod tajemnicami wiernym Pana Chrystusowym to pokazują i przed oczy ich kładą, a pokazują to w onéj ustawie Pańskiéj, którą sprawował na wieczerzy ostatecznéj, gdyż ona wieczerza skutek swój wzięła na krzyżu.

Mówi tak Pan na wieczerzéj: „To jest ciało moje, któré za was będzie wydané” - to sie ziściło na krzyżu.

Mówi zasię: „To jest kréw moja Nowégo Testamentu, ktora za was będzie przelana" - ziściło sie to na krzyżu, bo tam jest przelana do namniejszéj kropie.

Otóż aby sie wszytka sprawa pokazała i to, co był Pan obiecał pod widomémi osobami chleba i wina, i jako na krzyżu to skutkiem wypełnił, kapłani to na Mszéj niekrwawym obyczajem pokazują, poświącają pod dwiema osoboma, jako Chrystus Pan na wieczerzy - pokazują, jako tóż ciało na krzyż było przybité, zawieszoné i podniesioné, pokazują z osobna, jako onaż kréw Pańska była wytoczona $\mathrm{z}$ ciała i jako wypłynęła wespół $\mathrm{z}$ wodą na omycie grzéchów naszych - toć elewacyja albo podniesienié ciała i krwie Pańskiéj na Mszéj pokazuje ${ }^{75}$. Iż tedy oną sprawą wieczerzéj Pańskiéj kapłan krwawą onę wszytkę męki Pańskiéj ofiarę i sprawę wiernym chrześcijanom przed oczy kładzie i pókazuje, muszą sie wszystki sprawy Pana Chrystusowé przezeń wykonawać, musi sie ciało i kréw Pana Chrystusowa poświęcać, aby prawie doskonałymi i istotnémi rzeczami ony tajem-

75 Łac. elevatio - 'podniesienie', 'okazanie', tu: postaci eucharystycznych podczas ich konsekracji. 
nice były sprawowané. A po sprawie ich, gdy sie ta ofiara niekrwawa a własny wizerunk onéj ofiary krwawéj dokonywa, kapłan już po uczynieniu dzięk, po modlitwach za wszytek gmin chrześcijański, aby sie nad nimi Pan Bóg dla Syna swego zmiłować raczył i dla srogiéj męki jego, po wyznaniu powszechnéj wiary świętéj chrześcijańskiéj, po opowiedzeniu Ewanjelijéj i Pisma Świętégo, któré we Mszéj jest, koniec tym tajemnicom i téj niekrwawéj ofierze czyniąc, osoby widomé chleba i wina a własné ciało Pańskié i kréw przyjmuje - wiarę nie tylo swoję, ale wszytkich wiernych w tym pokazując, że ten Pan, który na wieczerzy pod osobami widomémi ciało i kréw swą zostawić raczył, ten na krzyżu w tymże ciele umarł, tęż kréw roźlał i choć od niewiernych Żydów za zginionégo był mian, a to w onym ciele swym wiecznie żywie i ono nam ku używaniu na wieki zostawić raczył, abyśmy go pożywając żyli na wieki. O czymeśmy dostateczniéj i szérzéj w Katechizmie naszym ${ }^{76}$, gdyśmy o Mszéj, co jest i dla czego jest, pisali, tam, kto chce dostateczniéj wiedzieć, niechaj czyta.

To już baczyć każdy może, dla któréj przyczyny we Mszéj kapłani dwie osobie przyjmują; kiedy ofiary niekrwawéj - to jest Mszéj - nie mają, tedy tak przyjmują ciało Pańskié pod jedną osobą, jako i człowiek pospolity chrześcijański. Przyczyna ta jest, że wiedzą i wierzą, iż nic mniéj ani więcéj pod dwiema, jedno tak jako i pod jedną osobą przyjmują - to jest zupełnégo Chrystusa przyjmują. I przetoć szafarze tajemnic Bożych: biskupi, kapłani, doktorowie chrześcijańscy, którzy przedniejszé mają miejsce miedzy wiernymi Chrysta Pana w Kościele, na Koncylijum Konstantieńskim drugiéj

76 O częściach mszy i ich porównaniu z łamaniem chleba z czasów apostolskich zob. M. Białobrzeski, Katechizm..., s. 350-351. 
osoby nie zakazali jakoby jakiéj rzeczy, która by w Kościele Chrystusowym na potomné czasy więcéj nigdy nie miała być, ale na czas zahamowali, aby błędy były uśmiérzoné, któré około tego Sakramentu wszczęły sie były i hojnie w sercach ludzkich panowały - gdzie kiedy by sie prawdziwa wiara około używania ciała Pańskiégo w serca ludzkié powróciła, błąd nestoryjański, Zwingliński i inszych gdyby był porzucon, snadnie by i druga osoba przywrócić sié mogła - nie dla potrzeby, ale dla zgody, boć więcéj by sie mieli frasować ludzie chrześcijańscy na zwinglijany, którzy ani ciała, ani krwie Pańskiéj im nie dawają, niż na starożytny Kościół święty, ktory w jednéj osobie nie znaki ku jedzeniu, jako oni, ale zupełnégo Chrystusa im dają ku używaniu; tam nic nie biorą, jedno znaki, a tego baczyć nie chcą tu w Kościele zupełnégo Chrystusa biorą, a przedsię krzywdę sobie najdują.

Pokazało sie łaskam waszym jaśnie, którym Pismem skaziciele zgody chrześcijańskiéj dowodzą swojego przedsięwzięcia i nauki swojéj o dawaniu dwu osób Sakramentu, lecz iż nad oné dowody swé mają téż przysmaki inszé, którémi to cukrują, żeby pod dwiema osoboma było dawané ciało i kréw Pańska.

g Naprzód mówią: „Jeśli dla obłędliwych i heretyckich nauk jest kielich odjęty, niechże teraz będzie przywrócony, bo gdy przywrócą kielich, siła sie do rzymskiéj starożytnéj wiary nawróci”. Na to tak im odpowiadamy:

Wiémy, że heretykowie do wszytkich inszych błędów wiary chrześcijańskiéj témi wrotami - to jest nauką dwojéj osoby - weszli i w serca ludzkié sie wkradli, ale żeby jakié pohamowanie przez dwie osobie Sakramentu błędów być miało, barzo wątpimy, gdyż sie temu zawżdy przypatrujemy, że w sakramentarskich zborzech ludzie ani ciała istotnie będącégo Chrysta Pana, ani krwie 
Lut[erus], Tom. 6, fol. 165 et Epi[stola] ad Ducem Georgium

Matt. 10, ver. 34

Chemnicius, $c a[\mathrm{p}]$. Com[munio] sub utraque specie świętéj jego przyjmują, jedno znaki zwiérzchnie chleba i wina, żadnéj mocy świątobliwości w sobie niémającé, a wżdy ich to namniéj nie obchodzi, i owszem, nie tylko że ich to nie obrusza, ale jeszcze prawą to Ewanjeliją zową - dla takich tedy dopuścić drugiéj osoby mało potym, bo bytności własnéj ciała Pańskiégo i krwie świętéj jego nie wierzą. A jeśli dla luteranów - i tam sie pożytku nie spodziéwaj, gdyżem łaskom waszym piérwéj powiedział, że on na wzgardę papieżowi i koncylijum, któré by dwie osobie postanowiło, i żadnéj osoby brać nie kazał. Lecz jednak aby kiedy do zgody przyść mogło z luterami, Kościół powszechny tego pragnąc, na Koncylijum Trydentskim to postanowił ${ }^{77}$, iż którébykolwiek królestwo tego potrzebowało, zawżdy to mieć może z dozwolenia Stolice Apostolskiéj, gdy tego żądać u téjże Stolice będzie, zachowawszy to, aby błąd nestoryjański w wiernych Pańskich miejsca nié miał, który sie powyższéj dosyć széroko pokazał.

Daj to, Panie Jezu Chryste, aby zgoda była w Kościele twym świętym, aleć sie pełni ono słowo twoje: „Nie przyszedłem pokoju puszczać na ziemię, ale miecz". Powiedają na to ${ }^{78}$, iż acz pod jedną osobą prawdziwé

77 Sobór Trydencki odraczał przyjęcie jednoznacznych postanowień co do udzielania Komunii wiernym świeckim pod dwiema postaciami, lecz po kolejnych pytaniach i prośbach kierowanych do ojców w imieniu cesarza stwierdzili oni: „Nikomu innemu nie udzieli się Komunii pod dwiema postaciami, jak tylko tym, którzy uwierzyli w tę prawdę [o pełnej obecności Chrystusa w Eucharystii - A.J.] i ją wyznali” oraz „używanie kielicha jest dozwolone tylko dla tych, którzy żałowali i wyspowiadali się zgodnie ze zwyczajem Kościoła katolickiego" (Sesja 21, II, 1, w: Dokumenty soborów powszechnych..., t. 4, s. 615).

78 Chemnicius - Georg Martin Chemnitz (1516-1571) - protestancki teolog, poeta, archeolog, historyk, współtwórca tzw. Formuły zgody, opracował dzieło Examinis Concilii Tridentini, w którym omawiał i poddawał krytyce postanowienia soboru; w części drugiej, w rozdziale De communione sub utraque specie (O Komunii pod dwiema postaciami) pisał: Agitur de necessaria consolatione et confirmatione 
używanié ciała Pańskiégo jest, ale dla tego nié mają być ludzie oszukawani, aby drugiéj osoby brać nié mieli dla więtszéj pociechy ich i dla doskonałégo w nich obietnic Pańskich wypełnienia. Ale na to łacną odpowiédź z powyższéj pokazanych obietnic Pańskich, który tak zacné obietnice w używaniu pod jedną osobą, jako i pod dwiema wiernym zostawić raczył.

gówią téż $\dot{z}^{79}$, że dla mdłych w wierze miałby papież Cassander et alii tego dopuścić i pozwolić, i na kształt Pawła świętégo dla pomnożenia wiary wszytkim narodom tym ugodzić, jako Paweł święty zstał sie Żydom jakoby Żydowinem, poganom bez Zakonu żywiącym zstał sie jakoby bez Zakonu, aby zyskał Panu Chrystusowi wszytki. „Tak by sie téż godziło wam i z waszym papieżem uczynić, a tą sprawą mdłym w wierze pofolgować”. Odpowiadamy im na to:

Nie wiemy, któré tu mdłymi w wierze rozumieją: jeśli nas, katoliki, krzywdę nam na tym czynią - już my dostatecznie wierzymy i wyznawamy, że pod jedną osobą zupełnégo Chrystusa przyjmujemy, żywé ciało jego, prawdziwégo onégo Chrystusa, który był i jest Bogiem i człowiekiem; o nas tedy to trudno rozumieć mają i mdłą nam wiarę próżno przypisować mają. Lecz

fidei, quae verbis illis continetur, deque pretiosissima obsignatione huius promissionis per exhibitionem sanguinis in remissionem peccatorum nostrorum fusi, „Mowa o koniecznym pocieszeniu i umocnieniu wiary, które zawierają się w tych słowach, a także o najcenniejszym poświadczeniu tej obietnicy przez ukazanie krwi rozlanej na odpuszczenie naszych grzechów", Examinis Concilii Tridentini, Frankfurt 1599, s. 347, przekład własny.

79 Cassander - Georg Cassander (1513-1566) - belgijski teolog i liturgista, pragnął przyczynić się do pojednania protestantów z katolikami, uznawał niektóre nauki protestanckie; jego dzieła trafiły w 1617 roku na indeks ksiąg zakazanych; poglądy na Eucharystię przedstawił w dziele De sacra communione christiani populi in utraque panis et vini specie consultatio, Köln 1564. 
1 Cor. 11, ver. 17; Galat. 2, ver. 11 et cap. 3 , ver. 1 ; Galat. 1, ver. 8

jeśli o sobie to rozumieją, że mdło wierzą - wstydzić by sie tego mieli, gdyż bez mocnéj wiary zbawienia niemasz, a wiara mdła słabo zbawia, a przedsię do takiéj wiary bez przestania inszé wiklą; lecz widzimy to jaśnie, iż prawdę o sobie mówią i piszą, iż mdłéj wiary są, bo gdyby w niéj potężni byli, tedy by sie w niéj tak często nie odmieniali, ale ich odmienność pokazuje, że wiary ich gruntu całégo niemasz, przeto i jéj budowanié odmienné i złé. Apostoła Pawła nam pokazują, że z Żydy jakoby Żyd był, z pogany jakoby poganin - wiémy, że nie tylo Paweł święty, ale i inszy apostołowie tóż czynili - to jest nowo nawróconym wiele przemilczawali około zwiérzchnich porządków bogomódlstwa, cerymonij, zwyczajów - ale gruntu wiary nie zamilczawali, i owszem, téj wiary którą szafowali, pilnie przestrzegali, sakramenta pilnie szafowali, źle ich używającym nie przepuszczali, ale je karali i fukali, jako Paweł święty karał Korynty, Galaty, i na ostatek i Piotrowi świętému apostołowi nie przepuścił ${ }^{80}$. Otóż i my w rzeczach, któré by sie wiary naszéj dotykały, nie mamy niwczym od niéj odstępować, a nie tylko ludziom $\mathrm{k}$ woli, ale $\mathrm{i}$ anjołom w tym folgować nie mamy, bo my gruntownéj wiary naszéj dla onych, którzy sie od nas swowolnie odłączyli, odstępować nie mamy. A chcą nie mdleć w wierze, niech sie upamiętają a przyjdą do nas, a my ich mdłość za wdzięczné przyjąwszy, apostolskim sposobem przyjmiemy je w duchu łaskawości i krewkość ich Kościół powszechny im pokazawszy, miłością ojcowską oné pocałuje. Co daj, Panie Jezu Chryste, któryś to dał, że uznali wiary swojéj mdłość i niepotężność, racz to

80 Spór świętych Piotra i Pawła dotyczył wątpliwości co tego, czy na przyjmujących chrzest pogan trzeba nakładać obowiązek przestrzegania Prawa żydowskiego (Ga 2,11-14). 
dać, aby sie upamiętali a z nami jedno o sakramentach twoich trzymali i w posłuszeństwie wiary twéj świętéj z nami żyli i ciebie chwalili. [...]

Chwalić tedy Pana Boga za to będę i chwalę, jeśli jaki pożytek w pozyskaniu dusz waszych a owiec moich pracą tą uczynię - nie mniéj Pana swego chwalić będę, jeśliż za tę pracą łajanié, pośmiéwanié i urąganié odnosić będę, gdyż to wiém pewnie, żem tu wiele im $\mathrm{k}$ lubości nie mówił, to sobie obrawszy, żem wolał słuchać Boga, jego Kościoła świętégo aniż ludzi, mając przed sobą onę naukę, iż téj wiary mocnie sie trzymać chcę i będę w tych leciéch śrzednich moich ${ }^{81}$, w ktoréj-em uródziwszy sie, niemówiątkiem był okrzczon, czego bym nie tylko sobie, ale każdému życzył. Dajże to, Panie Jezu Chryste, $\mathrm{z}$ łaski a z miłosierdzia swego, abyś otworzył serca wiernych swoich do jednostajnéj wiary swéj i do jednostajnégo używania ciała i krwie twéj naświętszéj, żeby ten Sakrament, któryś dla pokoju a zgody zostawić raczył swym wiernym, Sakrament pokoju i zgody był na świecie miedzy wiernymi twémi, i on pokój wieczny, który za obietnicami twémi nam przynosi, pokój żywota wiecznégo i żywot wieczny w królestwie twoim w nas wszytkich wiernych twoich pomnażał przez łaskę i miłosierdzié twoje, Panie, który z Ojcem i z Duchem Świętym żywiesz, prawdziwym Bogiem na wieki wieków, AMEN.

Summa wszytkiégo kazania ta jest:

Pokazuje naprzód, dla czego pod osobami chleba i wina Pan Sakrament ciała swego na wieczerzéj ostatecznéj zostawić raczył i jako Sakrament ten jest Sakrament wiary, miłości, pokoju i zgody.

81 Kazanie to zostało wygłoszone w Wielki Czwartek 1578 roku w Kamieńcu Podolskim; Białobrzeski miał wtedy ok. 49 lat. 
Jakim sposobem o używanié Sakramentu ciała Pańskiégo naprzód Grécki z Łacińskim, a potym w Europie miedzy zgodnymi chrześcijany niezgoda i rozerwanié sie zstało, i dla czego sakramentem, figurą etc., znakiem widomym jest nazwany od niéktórych Doktorów świętych. Nadto, jako i co o elementach albo osobach człowiek chrześcijański rozumiéć i wierzyć ma.

Dla których przyczyn Kościół Boży pod jedną osobą chleba używanié ciała i krwie Pana Chrystusowéj postanowić raczył i czego w tym postanowieniu uczy, jeśli téż tak pożytecznie ku zbawieniu pod jedną osobą, jako i pod dwiema osoboma ciało i krew Pańską przyjmować i jeśli wszytkim ta ustawa służy, tak kapłanom, jako i nie kapłanom, dostatecznie pokazuje. Téż pisma o dwojéj osobie jako sie rozumiéć mają, prawdziwie wykłada, ku zgodzie wszytki wierné napominając, któréj pragnąc, ta nauka potrzebna wiernym chrześcijanom jest pisana, Panu Chrystusowi niech będzie ku czci i ku chwale, AMEN.

\section{Bibliografia}

\section{Archiwalia}

Kiełczewski S., Historia monasterii Clarae Tumbae cum serie abbatum et fratrum, Biblioteka Książąt Czartoryskich, rkps 3652.

\section{Teksty}

Ambroży z Mediolanu św., O sakramentach, w: św. Ambroży z Mediolanu, Wyjaśnienie symbolu. O tajemnicach. O sakramentach, przeł., wstęp i oprac. L. Gładyszewski, Kraków 2004.

Augustinus Aurelius s., In Joannis Evangelium tractatus CXXIV, w: Patrologiae cursus completus. Series latina, ed. J.P. Migne, vol. 35. 
Augustyn św., De doctrina christiana. O nauce chrześcijańskiej, przeł., wstęp i oprac. J. Sulowski, Warszawa 1989.

Augustyn św., O państwie Bożym. Przeciw poganom ksiąg XXII, przeł. i oprac. W. Kornatowski, Warszawa 1977, t. 1.

Augustyn św., Objaśnienia Psalmów. Ps 1-36, przeł. i wstęp J. Sulowski, oprac. E. Stanula, Warszawa 1986.

Augustyn św., Pisma monastyczne, przeł. P. Nehring, M. Starowieyski, R. Szaszka, wprow. G. Lawless, wstęp i oprac. P. Nehring, Kraków 2002.

Augustyn św., Przeciw Faustusowi. Księgi XXII-XXXIII. Przeciw Sekundynowi, tłum. J. Sulowski, wstęp i oprac. W. Myszor, tłum. przejrzeli i popr. J. Gliściński et al., Warszawa 1991.

Białobrzeski M., Katechizm albo Wizerunk prawej wiary chrześcijańskiej [...], [b.m.w.] 1567.

Białobrzeski M., Kazanie na pogrzebie Zygmunta Augusta, w: Kazania funeralne, oprac. K. Panuś, M. Skwara, Kraków 2014.

Białobrzeski M., Kazanie o przyjmowaniu ciała i krwie Pana Jezu Krysta pod jedna osobą, Kraków: Andrzej Piotrkowczyk, 1579.

Białobrzeski M., Postylla ortodoxa, to jest Wykład świętych Ewanjelij niedzielnych $i$ świąt uroczystych przez caty rok [...]. Część pierwsza, od Adwentu do Wielkiejnocy, Kraków: Jan Januszowski, 1581.

Biblia w przekładzie księdza Jakuba Wujka z 1599 r., transkrypcja typu „B” oryginalnego tekstu z XVI w. i wstępy J. Frankowski, Warszawa 1999.

Boska Liturgia św. Jana Złotoustego, http://www.cyrylimetody.marianie.pl/pliturgia/ pliturgia3d.htm (dostęp: 22.05.2018).

Chemnitz G.M., Examinis Concilii Tridentini, Frankfurt 1599.

Cyprian św., Listy, przeł. W. Szołdrski, Warszawa 1969.

Gelasius Maiorico et Ioanni Episcopis, w: Patrologiae cursus completus. Series latina, ed. J.P. Migne, vol. 59.

Grotowski J., Sokrates albo o szlachectwie rozmowa [...], [Kraków: Łazarz Andrysowicz, b.r.w.].

Grzegorz Wielki św., O Agapicie świętym papieżu, w: św. Grzegorz Wielki, Dialogi, przeł. W. Szołdrski, wstęp J.S. Rojarski, oprac. E. Stanula, Warszawa 1969 [właśc. 1970].

Ignacy Antiocheński św., List do Kościoła w Filadelfi, w: Eucharystia pierwszych chrześcijan. Ojcowie Kościoła nauczają o Eucharystii, wybór i oprac. M. Starowieyski, wstęp M. Starowieyski, J. Miazek, A. Luft, Kraków 2014.

In solemnitate Corporis Christi, w: Missale Romanum, ex decreto Sacrosancti Concilii [...], Würzburg: Johann Hertz, 1698.

Leo Magnus s., Epistola LIX ad clerum et plebem Constantinopolitanae urbis, w: Patrologiae cursus completus. Series latina, ed. J.P. Migne, vol. 54. 
Leon Wielki św., Mowy, przeł., wstęp i oprac. K. Tomczak, Poznań-WarszawaLublin 1958.

Luther M., Formula missae et communionis pro Ecclesia Wittembergensi, w: Martin Luther Studienausgabe, Bd. 1, Berlin 1979, s. 365-386.

Opera Urbani Regii latine edita, Nürnberg: Johann vom Berg i Ulrich Neuber, 1562. Sancti Bernardi in Coena Domini sermo. De baptismo, sacramento altaris et ablutione pedum, w: Patrologiae cursus completus. Series latina, ed. J.P. Migne, vol. 183.

Pismo Święte Starego i Nowego Testamentu [Biblia Tysiąclecia], wyd. 4, Poznań 1984. Wieczerza Pańska w Księgach Wyznaniowych Luteranizmu. Mały Katechizm ks. dr Marcina Lutra: Konfesja Augsburska z 1530 r., https://www.luteranie.pl/ materialy/rozne_pisma/wieczerza_panska_w_ksiegach_wyznaniowych_luteranizmu,330.html (dostęp: 12.06.2018).

Wyznanie augsburskie (Konfesja Augsburska) z 1530 roku. 95 tez ks. Marcina Lutra $z 1517$ roku, [wstęp M. Uglorz, przeł z j. niem. A. Wanuta, przeł. z j. łac. J.W. Jackowski], Bielsko-Biała 1999.

\section{Opracowania}

Brzozowski M., Marcin Białobrzeski, w: Encyklopedia katolicka, red. F. Gryglewicz, R. Łukaszyk, Z. Sułowski, t. 2: Bar-Centuriones, Lublin 1976, s. 365.

Dokumenty soborów powszechnych. Tekst grecki, łaciński i polski, t. 1: Nicea I, Konstantynopol I, Efez, Chalcedon, Konstantynopol II, Konstantynopol III, Nicea II (325-787), układ i oprac. A. Baron, H. Pietras, [przeł. A. Baron et al.], Kraków 2001.

Dokumenty soborów powszechnych. Tekst grecki, łaciński, polski, t. 2: Konstantynopol IV, Lateran I, Lateran II, Lateran III, Lateran IV, Lyon I, Lyon II, Vienne (8691312), układ i oprac. A. Baron, H. Pietras, [przeł. A. Baron et al.], Kraków 2003. Dokumenty soborów powszechnych. Tekst łaciński, grecki, arabski, ormiański, polski, t. 3: (1414-1445) Konstancja, Bazylea-Ferrara-Florencja-Rzym, układ. i oprac. A. Baron, H. Pietras, [przeł. A. Baron et al.], Kraków 2003.

Dokumenty soborów powszechnych. Tekst łaciński i polski, t. 4: (1511-1870) Lateran V, Trydent, Watykan I, układ i oprac. A. Baron, H. Pietras, [tłum. A. Baron et al.], Kraków 2004.

Katalog Archiwum opactwa cystersów w Mogile, oprac. K. Kaczmarczyk, G. Kowalski, Kraków 1919.

Katalog inkunabułów Biblioteki Opactwa Mogilskiego oraz katalog inkunabułów klasztoru cystersów w Szczyrzycu, opisał G. Kowalski, Kraków 1915.

Korolko M., Klejnot swobodnego sumienia. Polemika wokót konfederacji warszawskiej w latach 1573-1658, Warszawa 1974.

Możejko J., Praktyka Komunii świętej pod obiema postaciami, „Liturgia Sacra” 20 (2014), nr 2(44). 
Panuś K., Zarys historii kaznodziejstwa w Kościele katolickim, cz. 2: Kaznodziejstwo w Polsce, t. 1: Od średniowiecza do baroku, Kraków 2001.

Stec W., Literacki kształt polskich polemik antyjezuickich z lat 1578-1625, Białystok 1988.

Zachara M., Komunia święta pod obiema postaciami, „Pastores” 65 (2014), nr 4. 